\title{
Calcareous nannofossil assemblages of the Late Cretaceous Fiqa Formation, north Oman
}

\author{
Zainab Al Rawahi and Tom Dunkley Jones \\ Department of Earth Sciences, University of Birmingham, Birmingham, B15 2TT, UK \\ Correspondence: Zainab Al Rawahi (alrawahi.zainab@gmail.com)
}

Received: 16 August 2018 - Revised: 9 January 2019 - Accepted: 4 February 2019 - Published: 28 February 2019

\begin{abstract}
This study presents the first detailed calcareous nannofossil assemblage data from the Late Cretaceous succession of the subsurface Aruma Basin, north Oman. The taxonomic description and documentation of assemblage composition are based on extensive quantitative analysis of ditch cuttings and side-wall samples from eight hydrocarbon exploration wells across north Oman. The samples studied from those wells cover the Coniacian to earliest Maastrichtian deep marine shales and marls of the subsurface Fiqa Formation. These finegrained siliciclastic deposits often yield moderately to well-preserved nannofossil assemblages, especially in the Campanian intervals. Consequently, diverse assemblages have been recorded from the Fiqa Formation, with a total diversity of $\sim 200$ species, including two new species, Staurolithites ormae sp. nov. and Chiastozygus fahudensis sp. nov., which are illustrated and described. Extensive imaging of this diversity is provided here, as are stratigraphic distributions of the main components from a key reference well in north Oman, W-4. Poorly described groups such as Staurolithites are closely investigated and their utility for stratigraphic applications is highlighted. Relative abundances of nannofossil taxa with strong palaeoenvironmental preferences have revealed new insights into the palaeo-productivity of the basin. High-fertility species like Discorhabdus ignotus, Biscutum constans and Zeugrhabdotus erectus show substantial variations in abundance throughout the Fiqa Formation, reflecting long-term shifts in the productivity conditions of the basin. This is supported by abundance patterns of Watznaueria barnesiae and Micula staurophora that show a broadly inverse correlation with the high-fertility species. The Fiqa Formation represents a key regional seal unit for the Cretaceous hydrocarbon reservoirs of Oman, as well as being a productive unit elsewhere in the Arabian Peninsula. Beyond the Aruma Basin of Oman, this study will provide a key reference point for future biostratigraphic or palaeoenvironmental analyses of the Late Cretaceous calcareous nannofossil assemblages across the Middle East and other southern Tethyan areas.
\end{abstract}

\section{Introduction}

The Fiqa Formation sensu Hughes Clark (1988) and Forbes et al. (2010) in the subsurface of northern Oman provides a unique window into truly pelagic, Late Cretaceous ecosystems of the Arabian Peninsula. Deposited through $\sim 15 \mathrm{Ma}$, from the Coniacian to earliest Maastrichtian, it consists of very thick sequences of marls and shales, interpreted as representing deposition in a deep marine setting within a foreland basin developed in the north of Oman (Glennie et al., 1974). These sediments often yield well-preserved and abundant pelagic microfossils, including calcareous nannofossils, that have great potential for environmental, evolutionary and biostratigraphic studies. The Fiqa Formation and its equivalents across the Arabian Peninsula are key regional seals for Early to middle Cretaceous hydrocarbon reservoirs. These units are also hydrocarbon productive in some localities. The rich nannofossil recovery within the Fiqa Formation has the potential to resolve some of the subsurface stratigraphic complexities related to regional correlations within a thick and homogeneous yet assumed diachronous lithology by providing a higher-resolution correlation between different hydrocarbon wells. Past unpublished industry studies have touched on these applications, but generally have focused on stratigraphically or spatially limited well-to-well correlations (e.g. Lauer, 1973; Sissingh, 1974; Prins and Roersma, 
1983; Varol, 1996, 1997). None of these unpublished reports describe the calcareous nannofossil assemblage composition, provide extensive images, or integrate their findings into a regional or global context such as the globally applied zonation schemes of Sissingh (1977), Perch-Nielsen (1985) and Burnett (1998). Although substantial micropalaeontological analyses associated with hydrocarbon exploration activity have also been undertaken in the region for more than 40 years, the vast majority of this work and data remains unpublished in industry reports.

The few available published studies of Late Cretaceous calcareous nannofossils in the Middle East are limited to biostratigraphic applications. This includes the biostratigraphic study of Coniacian-Maastrichtian chalky and marly sequences of Lebanon by Müller et al. (2010) in which they provided a brief description of the nannofossil markers used for biostratigraphic subdivision as part of a general revision of the Cretaceous and Cenozoic stratigraphy of the country. Other nannofossil biostratigraphic studies include the late Campanian-Maastrichtian upper Mahara group of Yemen (Al-Wosabi and Alaug, 2013), the late Santonian to Maastrichtian Abu Roash and Khoman formations in the northwestern desert of Egypt (Mandur, 2016), the Coniacian to Maastrichtian Themed and Sudr formations of Sinai, Egypt (Faris and Abu Shama, 2006; Farouk and Faris, 2012), and the late Campanian to early Maastrichtian Shiranish Formation of NE Iraq (Farouk et al., 2018). In Iran, Late Cretaceous nannofossil biostratigraphy has been studied by several authors, but the most detailed studies are achieved by Razmjooei et al. (2014), Foroughi et al. (2017) and Razmjooei et al. (2018) for the Gurpi and Abtalkh formations of south and north Iran, respectively, in which nannofossil biozonations were developed for the studied sections. All of these studies mostly focus on solving stratigraphic problems like age constraint and hiatus recognition, whereas very little information is published on assemblage composition, their changes through time or their potential palaeoenvironmental significance.

The Late Cretaceous epoch was one of the warmest periods with a global sea level that was $100 \pm 50 \mathrm{~m}$ higher than today (Miller et al., 2005). The sea level record of Cramer et al. (2011) indicates a relatively high sea level throughout the Coniacian to Maastrichtian with minor variations, like the increase in sea level during the Santonian and sea level drop during the mid-Campanian, CampanianMaastrichtian boundary and toward the end Maastrichtian. Global compilations of benthic foraminiferal oxygen-isotope $\left(\delta^{18} \mathrm{O}\right)$ data by Friedrich et al. (2012) indicate conditions of peak warmth close to the Cenomanian-Turonian boundary, with warm, yet relatively cooler climates persisting into the Coniacian and Santonian. In the early Campanian, benthic foraminiferal $\delta^{18} \mathrm{O}$ compositions shift to more positive values by over $1 \%$, indicating a significant $\left(>4^{\circ} \mathrm{C}\right)$ cooling of high-latitude oceans (Friedrich et al., 2012). The best available long-term records of ocean surface temperatures through this interval also indicate substantial cooling, of a similar magnitude, through the Campanian (Linnert et al., 2014b).

The Late Cretaceous is associated with an acme in calcareous nannofossil diversity. The detailed record of Cretaceous nannofossil diversification by Bown et al. (2004) shows a diversity peak after the Turonian that continued until the midMaastrichtian before it began to decline toward the K-Pg boundary. The highest diversity is recorded in the Campanian, a time that is also marked by large coccolith size, a characteristic feature that continued until the mid-Maastrichtian. Compared to the Campanian diversification, the Coniacian and Santonian are characterised by low diversity and a low turnover rate (Burnett, 1998). Bown et al. (2004) suggest that cooling within a greenhouse-mode climate system (e.g. Campanian-early Maastrichtian cooler climates) may have stimulated diversification via greater differentiation of the photic zone environment, biogeographic partitioning and increased numbers of endemic taxa at both low and high latitudes. Keller (2008) also related the increased diversity of microfossil and nannofossil groups during the Cretaceous cooling periods to increased weathering, runoff, upwelling and nutrient cycling, while more stable diversity is associated with high sea levels during the warmest Cretaceous intervals (e.g. Turonian-Santonian).

During the Late Cretaceous, deposition of the Fiqa Formation occurred on the northeastern margin of the AfricanArabian plate at an equatorial palaeolatitude in the eastern Tethys. The detailed documentation of calcareous nannofossil assemblages at this location thus also fills a gap between the austral and western Tethys provinces. Given the quality of preservation and stratigraphic continuity of nannofossil assemblages from the Fiqa Formation, they will be important for future assessments of Late Cretaceous provincialism. The temporal coverage provided by the Fiqa Formation, from the Coniacian to earliest Maastrichtian, and the quality of preservation of truly tropical calcareous nannofossil assemblages, also has the potential to constrain patterns of tropical diversity. Such data will help to address the question of whether the continued rise in global diversity is primarily driven by the diversification of mid- to high-latitude flora through the Late Cretaceous.

This paper aims to address a number of the questions outlined above by providing the first detailed study of calcareous nannofossil assemblages through the Late Cretaceous Fiqa Formation. The excellent preservation within the formation includes some rarely reported and poorly documented Late Cretaceous taxa. The quality of this preservation provides the basis for further application of these assemblages for biostratigraphic and palaeoenvironmental interpretations. It is the aim of this paper to provide a first overview of the taxonomy and broad patterns of calcareous nannofossil assemblage change through the Fiqa Formation. The paper will also provide a key reference point for other studies of Late Cre- 
taceous nannofossil assemblages across the Middle East and other southern Tethyan areas.

\section{Depositional setting of the Fiqa Formation}

In north Oman the carbonate platform that had developed on a passive continental margin during the Early Cretaceous was progressively flooded during Coniacian times, which resulted in the deposition of extensive deep marine shales and marls of the Fiqa Formation in a foreland basin setting (Glennie et al., 1974) referred to as the Aruma Basin. This basin formed as a result of crustal loading associated with over-thrusting and emplacement of oceanic crust known as the Sumail ophiolite and other associated sheets onto the eastern margin of the Arabian Peninsula (Bechennec et al., 1990). This occurred as a result of a major compressional tectonic phase associated with the closure of the Neotethys Ocean (Lippard et al., 1986). The basin was deeper proximal to the thrusted sheets in the north and west of Oman and shallowed toward the southeast as seen from seismic and well data (Forbes et al., 2010). Using the palaeolatitude calculator method of van Hinsbergen et al. (2015), the basin was located at a tropical palaeolatitude during the time of deposition, which is consistent with regional palaeogeographic reconstructions (Fig. 1).

The subsurface Fiqa Formation is part of the Late Cretaceous Aruma Group of Oman and is widespread throughout Oman, reaching a thickness of more than $1 \mathrm{~km}$ in the northwest (Boote et al., 1990). It is separated into lower shale-dominated facies like the Shargi Member and upper carbonate-dominated facies like the Arada Member (Forbes et al., 2010) (Fig. 2b). The formation is thicker and predominantly pelagic shale in the north, thinning and changing into shallower marine facies to the south and southeast of Oman (Forbes et al., 2010) (Fig. 2c). In the northern Oman mountains (known as the Al-Hajar Mountains), the time equivalent lithostratigraphic units to the subsurface Fiqa Formation are the local, nearshore facies mapped as the Muti Formation, Juweiza Formation and Qahlah Formation (Glennie et al., 1974). These formations were deposited at the northern margins of the basin in close proximity to the advancing thrust sheets (Robertson, 1987). The Juweiza and Qahlah formations are also referred to the subsurface clastic-dominated intervals proximal to the Oman mountains (Fig. 2c). The Fiqa Formation is chronostratigraphically correlated with the Gurpi Formation southeast of the Zagros Mountains of Iran, the Aruma Formation in Kuwait and Saudi Arabia, and the Aruma Formation and the Fiqa Formation of the United Arab Emirates (Ziegler, 2001) (Fig. 2a).

Some of the first published foraminiferal biostratigraphy work assigned an age of Santonian to Campanian to the Fiqa Formation (e.g. Glennie et al., 1974). The micropalaeontological facies have since been extensively studied for exploration purposes, with the most recent age assignment of late Coniacian to late Campanian based on the local planktonic foraminiferal zonation schemes of Sikkema (1991), revised by Osterloff et al. (2001) and Packer (2002). Micropalaeontological analysis from northern Oman by Packer (2002) indicates a neritic environment developed during the deposition of the Fiqa Formation within the early stages of foreland basin development. It deepened into upper to middle bathyal settings with rapid rates of sediment deposition during most of the Santonian to middle Campanian. These deep marine conditions were interrupted by several episodes of shallowing of sea level. During most of the late Campanian to Maastrichtian, sea level continued to fall with a generally highenergy, shallow marine environment developing over most of north and interior Oman.

\section{Material and methods}

The study is based on the quantitative analysis of 230 subsurface samples provided by the Petroleum Development Oman (PDO) from the Late Cretaceous Fiqa Formation. Samples included ditch cuttings and side-wall cores from nine hydrocarbon exploration wells from north and central Oman (Fig. 2a). Samples were prepared as simple smear slides following the standard technique of Bown and Young (1998). The cascading count technique of Styzen (1997) is followed using 100 fields of view. Species observation and description are based on light microscopy in cross-polarised and phase-contrast light using a Zeiss Scope.A1 at $1250 \times$ magnification and GXM-XPLPOLTEC- 2 at $1000 \times$ magnification. Digital images were captured with Q-imaging and GXCAMU3-5 cameras using QImaging and ToupLite software. All of the samples have been used to identify and image taxa and to understand the general patterns of assemblage change; one reference section from north Oman, W-4, is used here to provide a more detailed description of the changing nannofossil assemblage composition observed through the Fiqa Formation and its potential palaeoenvironmental and palaeogeographic applications. The total number of samples analysed from W-4 is 50. An additional 91 samples from W-4 are analysed for element concentrations using X-ray fluorescence (XRF). Samples are prepared as pressed pellets following the method of Takahashi (2015) and analysed using a Bruker S8 TIGER WDXRF elemental analysis system. Calcium weight percentage is presented in this study.

\section{Results}

\subsection{Stratigraphic age}

Based on calcareous nannofossil biostratigraphy (Zainab Al Rawahi and Tom Dunkley Jones, unpublished data), the studied Fiqa successions span the late Coniacian to late Campanian nannofossil Zones UC11 to UC16 and possibly the earliest Maastrichtian UC17 nannofossil zone of the Burnett (1998) scheme for the Tethyan realm $\left(\mathrm{UC}^{\mathrm{TP}}\right)$. 


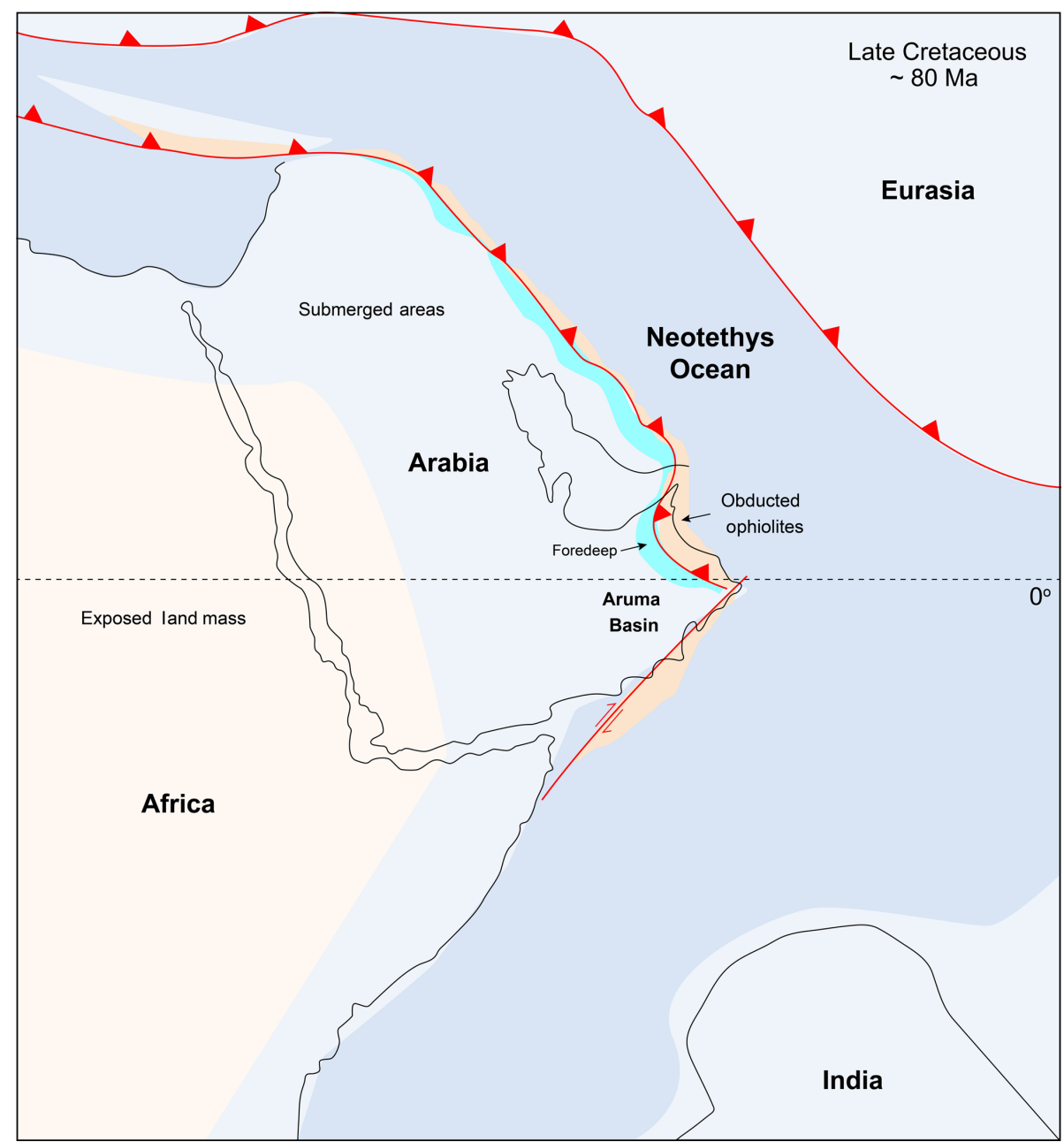

Figure 1. Palaeoceanographic and tectonic reconstruction of Arabia showing the location of the Aruma Basin. Modified from Barrier and Vrielynck (2008) with information from van Hinsbergen et al. (2015).

The recovered succession within W-4 is dated to lie within the late Coniacian to early Campanian Zones UC11 to UC14 (Fig. 4). The identification of UC14 is based on the presence of Bukryaster hayi and base Broinsonia parca parca at $111 \mathrm{~m}$; that of UC12-13 is based on the observation of base Broinsonia parca parca to top Lithastrinus septenarius at $1280 \mathrm{~m}$. UC11 is based on the top Lithastrinus septenarius and the presence of Quadrum gartneri.

\subsection{Preservation}

Due to the susceptibility of coccoliths to dissolution and overgrowth, the preservation of nannofossil in the study wells can be variable across lithologies and with different burial depths. Quantifying the quality of preservation through a succession is important as variations may cause preservational bias on the resulting assemblage data (Thierstein, 1980; Roth, 1984). To describe the preservation, a general preservation scale has been applied here, which is outlined below.

- VG: very good - no evidence of dissolution and/or recrystallisation, no alteration of primary morphological characteristics, and specimens identifiable to the species level.

- G: good - little or no evidence of dissolution and/or recrystallisation; primary morphological characteristics unaltered or only slightly altered; specimens identifiable to the species level.

- M: moderate - specimens exhibit some etching and/or recrystallisation; primary morphological characteristics somewhat altered; however, most specimens identifiable to the species level.

- P: poor - specimens were severely etched or overgrown; primary morphological characteristics largely 


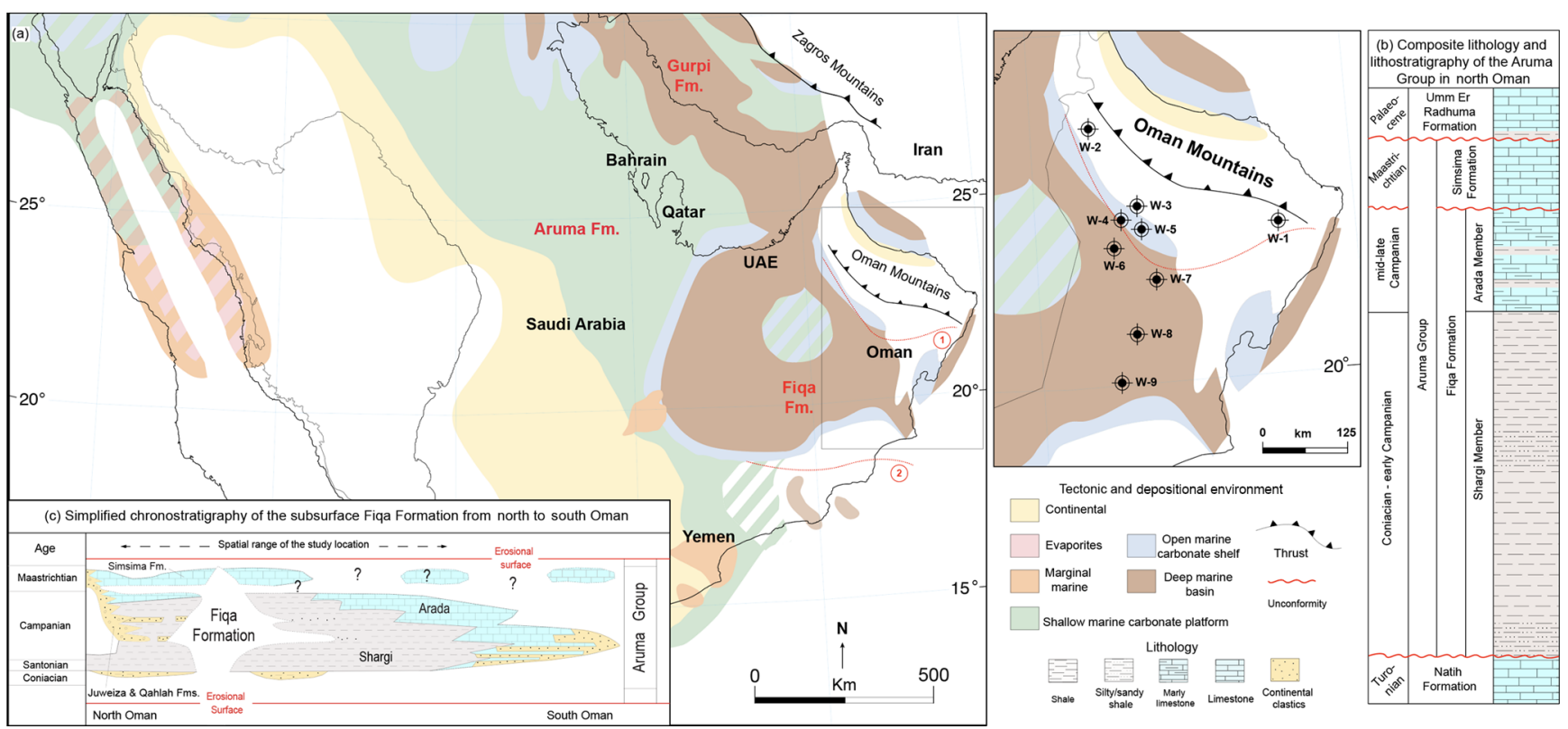

Figure 2. (a) Location of the study wells in a regional palaeofacies map of the Late Cretaceous (modified after Ziegler, 2001) showing the deposition of the Fiqa Formation and its equivalents (Gurpi and Aruma formations): (1) outline of the foredeep part of the basin in north Oman; (2) extent of the Aruma Basin in Oman. (b, c) Lithology, lithostratigraphy and chronostratigraphy of the Aruma Group in Oman (adapted from Forbes et al., 2010).

destroyed; fragmentation has occurred; specimens often could not be identified at the species and/or generic level.

Based on a visual inspection of etching and overgrowth the preservation is very good to good in the soft, grey shale layers of the Shargi Member and in the soft, grey marl layers of the Arada Member. The quality of preservation decreases to moderate as the amount of coarser clastic input increases up-hole in well sections, for example in the silty and sandy grey shale horizons of the Shargi Member. Intervals of highly compacted shale within the lower Shargi Member are sometimes present and have moderate to poorly preserved nannofossil assemblages with indications of dissolution and overgrowth. A further reduction of preservation is recorded in the carbonate-rich, white chalk and argillaceous limestone layers of the Arada Member, where nannofossil recovery is very poor.

In the well-preserved nannofossil assemblages of the Campanian and late Santonian intervals, the assemblages are characterised by the common presence of coccospheres (e.g. Plate 7, fig. 37; Plate 8, fig. 10, Plate 11, fig. 36) and consistent occurrence of holococcoliths such as Bilapillus, Munarinus, Octolithus, Ottavianus, Russellia and Nicholasia (Plates 8-9). The presence of such a diversity of holococcolith species is indicative of excellent preservation with minimal taphonomic or diagenetic dissolution (e.g. Roth and Bowdler, 1981; Roth, 1984). These intervals are also characterised by the abundance of small placolith species, such as Biscutum constans (Plate 7, figs. 25-27) and Discorhabdus ignotus (Plate 7, figs. 35-37), and murolith coccoliths like Corollithion species (Plate 7, figs. 11-14) and small Zeugrhabdotus species (Plate 2, figs. 26-42; Plate 3, figs. 121). Moreover, fine central area structures such as crossbars, plates and perforations are preserved in many species; this includes, for example, the case of Broinsonia verecundia (Plate 1, figs. 22-28) and Helicolithus blairiae (Plate 6, figs. 33-42), for which fine central area structures are observed that are not seen either in the holotype or paratype specimens. Well-preserved larger taxa are characterised by the presence of fine central area structures, as observed in the plate perforations of Arkhangelskiella cymbiformis (Plate 1, figs. 3-4). Generally, the quality of nannofossil preservation decreases slightly and assemblages are reduced in diversity and abundance down-hole toward the Coniacian intervals.

\subsection{Species richness}

Across the study wells, highly diverse assemblages (> 70 species per sample) are present within the Campanian intervals. Species richness is only slightly lower in the early Maastrichtian, with lower diversities of holococcoliths, Stauorolithites and Broinsonia and an absence of Corollithion and Ahmuellerella, and during the Santonian and early Coniacian intervals with a peak of 40-55 species per sample in the shale and grey marl intervals. Such high diversity compares favourably with the global diversity estimates of Bown et al. (2004) for the Late Cretaceous. In W-4 (Fig. 3), the highest species richness is present in the outer shelf set- 
tings (as defined by the microfaunal associations, PDO data), rather than in shallower shelf or deeper oceanic settings which are characterised by reduced abundances and species richness. These intervals are also correlated with increased calcium carbonate content $(\mathrm{Ca}>10 \mathrm{wt} \%)$ (Fig. 3).

In general, the overall average diversity is around 40 species per sample, which changes only slightly depending on nannofossil preservation and the loss of smaller and solution-sensitive taxa. This might reflect a general stability in the depositional environment. Even though the species richness does not change dramatically, the assemblages are continuously fluctuating in composition, which is not reflected in the nearly homogeneous lithology of the formation. The main trends of the assemblage fluctuations are discussed below.

\subsection{Assemblage composition}

\subsubsection{General assemblage composition}

Throughout the Fiqa Formation in the study wells, calcareous nannofossil assemblages are characterised by high abundances of the placolith coccoliths Watznaueria barnesiae and Prediscosphaera cretacea with an average abundance of $20 \%-25 \%$, whilst peak abundances can range up to $60 \%-$ 64\%. Prediscosphaera species (Plate 8, figs. 2-6, 12) are dominated by $P$. cretacea and $P$. grandis, with less common taxa including $P$. spinosa, $P$. bukryi and $P$. stoveri. Watznaueria barnesiae (Plate 8, figs. 9-10) is dominant, with minor contributions from other species (Plate 8, figs. 11, 13-16, 18-19) including W. bayacki, W. quadriradiata and W. ovata, which occur more frequently in the upper parts of early Campanian intervals. Watznaueria fossacincta and W. biporta are very rare and sporadic. Other frequently occurring species include the placolith coccoliths Cribrosphaerella ehrenbergii (Plate 7, figs. 20-22), Biscutum constans (Plate 7, figs. 2527) and Discorhabdus ignotus (Plate 7, figs. 35-37) and the murolith coccoliths Eiffellithus (Plate 5, figs. 2-42; Plate 6, figs. 1-9), Corollithion (Plate 7, figs. 11-14), Zeugrhabdotus (Plate 2, figs. 26-42; Plate 3, figs. 1-21) and Tranolithus (Plate 2, figs. 14-25). Common nannoliths include Micula staurophora (Plate 11, figs. 14-20). Cylindralithus biarcus, Manivitella pemmatoidea, Loxolithus armilla and Ahmuellerella octoradiata are also common and show a consistent presence throughout the formation. The dominance of these taxa is typical for Late Cretaceous Tethyan assemblages (e.g. Wagreich, 1992; Lees, 2007). The assemblage patterns of the main genera from W-4 are represented in Fig. 4. It is considered as an example well from north Oman with the most continuously sampled interval of the Fiqa Formation, covering the Coniacian to early Campanian. The changing patterns of the main groups and their composition in W-4 are described below.

Cribrosphaerella ehrenbergii is common and consistently present with peaks in abundance of around $10 \%$ (Fig. 4). The rim can have irregular or elliptical outlines. However, these rim outlines are very rare and encountered only in the more abundant and well-preserved samples. Corollithion is another common genus that can contribute to more than a third of the total assemblage during the early Campanian (Fig. 7). This genus is represented by common $C$. signum, less abundant C. exiguum and rare occurrences of C. kennedyi. Zeugrhabdotus species represent a consistent component of the assemblage throughout the section with an average abundance of $3 \%$ of the total assemblage (Fig. 4). The most common species include $Z$. diplogrammus, $Z$. erectus, $Z$. bicrescenticus and $Z$. clarus. Rare occurrences of $Z$. cf. xenotus, $Z$. trivectis, $Z$. sigmoides, $Z$. scutula, $Z$. praesigmoides, $Z$. noeliae, $Z$. howei, $Z$. embergeri and Z. acanthus have been recorded sporadically in the formation. Zeugrhabdotus biperforatus and $Z$. noeliae, which are important markers in the UC global zonation scheme of Burnett (1998), are very rare with inconsistent occurrences in this section. These low abundances make determining their biostratigraphically important first and last occurrences difficult. Tranolithus species (Fig. 4), represented mainly by T. orionatus $(<1 \%$ to $16 \%$ ) and $T$. minimus ( $<1 \%$ to $4 \%$ ), are a very important component of the assemblage throughout the Fiqa Formation, although T. gabalus is rare and sporadic. Micula species (Plate 11, figs. 41-29) are common and mainly represented by $M$. staurophora, which is highly abundant in several intervals and increases in abundance from $<1 \%$ to $14 \%$ of the total assemblage during the early Campanian (Fig. 7). Retacapsa species (Plate 7, figs. 39-42) are consistently present throughout the Fiqa Formation, with $R$. angustiforata being the most dominant, followed by $R$. crenulata and $R$. surirella, whilst $R$. schizobrachiata and $R$. ficula are rare. There is an important and continuous abundance peak in Retacapsa, which increases from $3 \%$ to $14 \%$, toward the upper parts of early Campanian intervals (Fig. 4). Gartnerago, mainly represented by G. segmentatum and G. obliquum, is another consistent component of the assemblages that fluctuates in abundance from $0.1 \%$ to $\sim 3 \%$. Gartnerago praeobliquum is less common, although smaller and very rare morphotypes $G$. cf. ponticula and $G$. cf. praeobliquum are present. Rhagodiscus species of $R$. angustus, $R$. splendens and $R$. reniformis are present throughout the Fiqa Formation but make up only about $1 \%$ of the total assemblage. Placozygus (Plate 2, figs. 7-10) is observed with a generally low abundance but with consistent occurrences and is mainly represented by $P$. spiralis, with rare occurrences of $P$. fibuliformis. Calciosolenia fossilis (Plate 8, fig. 17) is very rare but found sporadically in many intervals. Holococcoliths (Fig. 4) are diverse and represented by common genera of Calculites (Plate 8, figs. 26-41), Lucianorhabdus (Plate 9, figs. 3-9) and Owenia (Plate 9, fig. 10), as well as rarer genera (Plate 9, figs. 11-41) of Bilapillus, Munarinus, Octolithus, Ottavianus, Russellia, Duocameratus and Nicholasia.

Characteristic features of the late Campanian to early Maastrichtian intervals of the Fiqa Formation that are not 

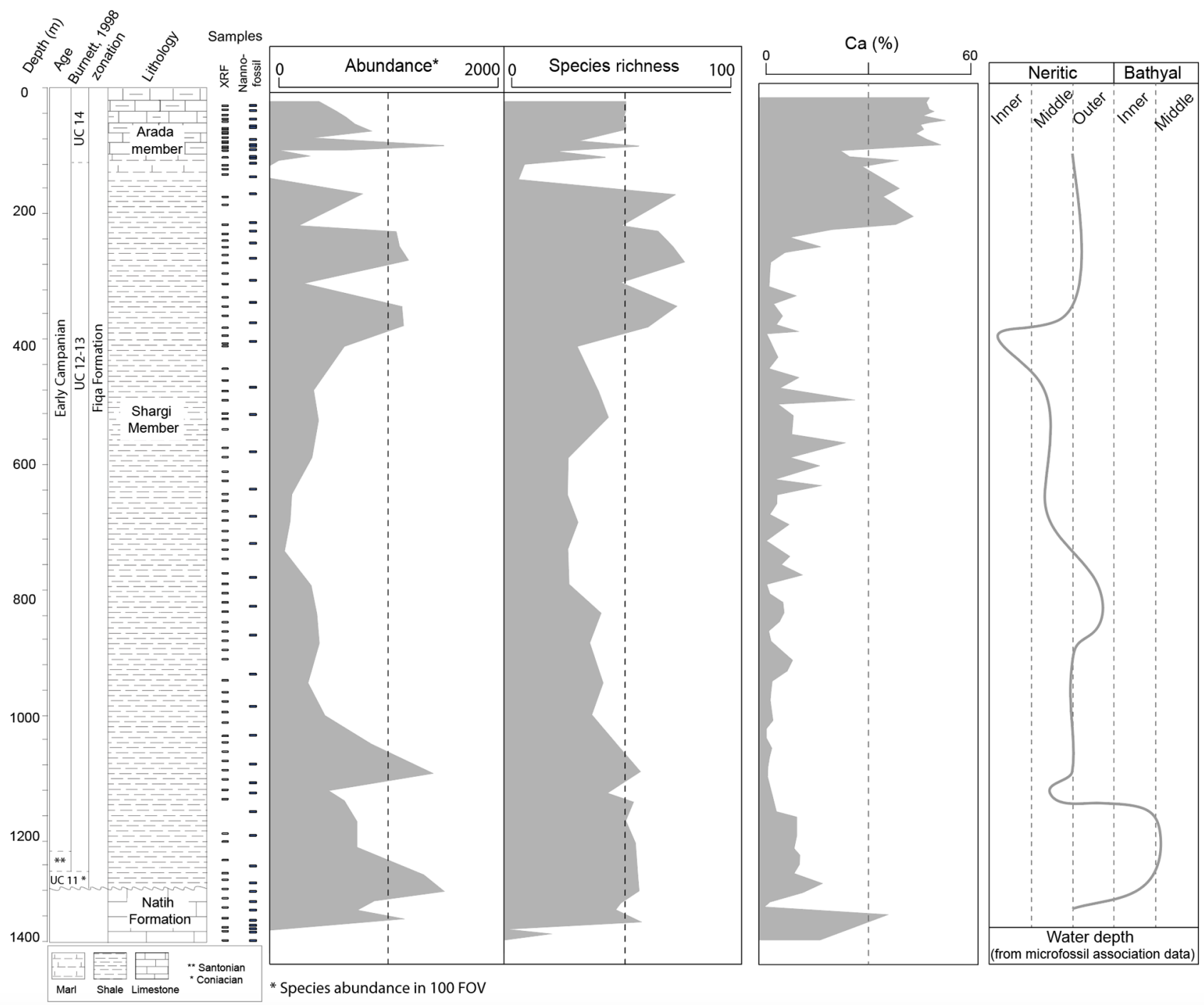

Figure 3. Nannofossil abundance and diversity in the Fiqa Fm. compared to Ca wt \% and palaeo-depth, W-4.

encountered in W-4 but in W-7 and W-8 include the more frequent occurrence of Helicolithus (Plate 6, figs. 10-42) and Uniplanarius (Plate 11, figs. 4-10) species. Helicolithus species are diverse, consistently present and dominated by $H$. compactus and $H$. trabeculatus. The abundance of Uniplanarius species $-U$. sissinghii, $U$. gothicus and $U$. trifidus is generally very low, but this gradually increases toward the latest Campanian and early Maastrichtian intervals, reaching $2 \%$ of the total assemblages in W-8. In W-4, Uniplanarius species are absent and Helicolithus species are represented by $H$. leckiei that is found sporadically throughout the formation and $H$. blairiae that is consistently present during most of the Santonian and Coniacian intervals. The top of $H$. blairiae within the Santonian could be of biostratigraphic significance in the area.

The overall assemblage composition and characteristics are similar to the Late Cretaceous Tanzanian assemblages studied by Lees (2007). This includes the identification of several of the new heterococcolith species described from the Tanzanian Drilling Project materials like Eiffellithus lindiensis (Plate 5, figs. 12-15), Staurolithites halfanii, S. handleyi (Plate 4, figs. 1-4), S. ngurumahambaensis (Plate 4, figs. 1922) and the holococcolith species Bilapillus wadeae (Plate 9, figs. 14-15), Calculites cyclops (Plate 8, figs. 34-41) and Duocameratus leariae (Plate 9, figs. 38-39). Assemblages are also similar to the Tanzanian assemblages in the frequent occurrence of holococcoliths and very small $(<3 \mu \mathrm{m})$ taxa. A full list of the taxa present in the analysed samples is available in the Supplement. 


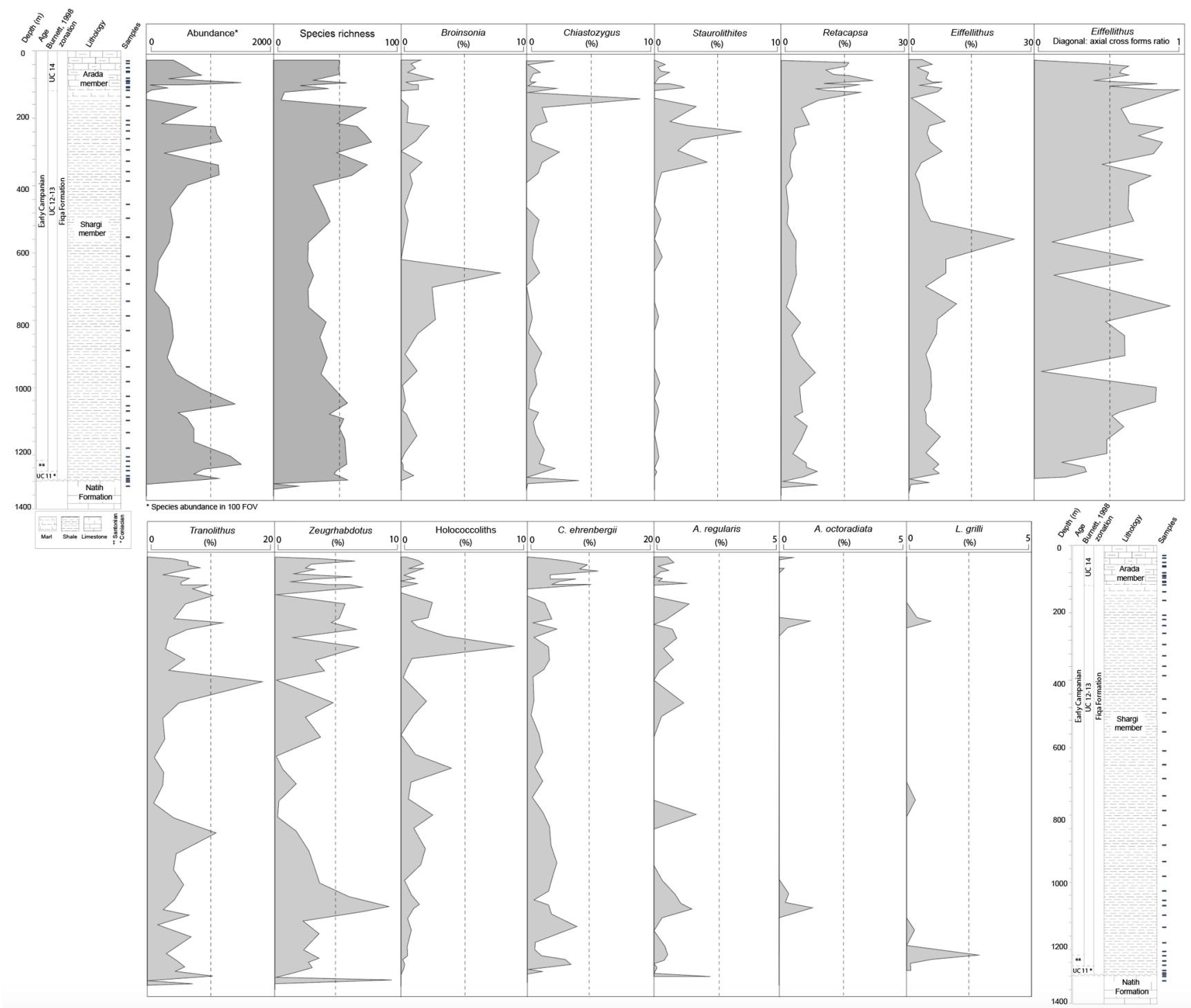

Figure 4. Abundance distribution patterns of the main components in the nannofossil assemblages, W-4.

\subsubsection{Notes on the taxonomy and assemblage composition of the common Late Cretaceous genera in the Fiqa Formation}

Arkhangelskiella. Occurrences of the genus Arkhangelskiella are sporadic in most intervals, with generally low abundances. This group has been widely studied due to its high variability in coccolith size and its possible evolutionary (e.g. Varol, 1989; Thibault, 2010) and palaeoenvironmental (e.g. Linnert and Mutterlose, 2009a) significance. Arkhangelskiella cymbiformis, for instance, has been subdivided into several morphogroups based on coccolith size and rim width (e.g. Varol, 1989; Thibault, 2010). In this study, however, due to the relative rarity of this genus, the group is subdivided into three main species following the definition of Burnett (1997). Arkhangelskiella cymbiformis (Plate 1, figs. 3-
4) includes all large species $(>8 \mu \mathrm{m})$ with relatively narrow rims $(<1 \mu \mathrm{m})$, whilst all smaller forms are included within A. confusa (Plate 1, figs. 1-2). All large forms with a thick $\operatorname{rim}(>1.5 \mu \mathrm{m})$ are included into A. maastrichtiensis (Plate 1, figs. 5-6).

There is one exceptional interval during which this group becomes very common in the few latest Campanian to early Maastrichtian samples from W-8, for which specimens show great variation in coccolith size and rim width (e.g. Plate 1, figs. 5-6). Hence, the morphometric subdivision of Varol (1989) and Thibault (2010) could be potentially applied only in these intervals. These samples are the only ones in which Arkhangelskiella maastrichtiensis, which has a very thick rim relative to $A$. cymbiformis and A. confusa, has been recorded. The observed specimens of A. maastrichtiensis, however, show great size variations and could be equivalent 
to the morphogroups A. cymbiformis var. N (small), A. cymbiformis var. W (medium) and $A$. cymbiformis var. SW (large) of Thibault (2010). Although these distinctions have potential for future morphometric application, this subdivision is not followed here as it is beyond the scope of this study and only few samples exhibited such variation.

Broinsonia. Species of the genus Broinsonia represent one of the most significant groups within the Fiqa Formation (Fig. 4), with several species that either evolved and/or go extinct within the studied succession. Four main species of Broinsonia - B. signata, B. enormis, B. parca and B. verecundia (Plate 1, figs. 7-28) - have been identified and we follow the taxonomy of Linnert et al. (2014a) and Wise (1983). In their biometric study, Linnert et al. (2014a) grouped all specimens with a cross-shaped central area structure into $B$. signata and all medium-sized specimens with a platelike central structure into $B$. enormis. In the studied succession, B. signata is consistent throughout the late Coniacian to early Campanian intervals, before its abundance gradually decreases and it eventually disappears in the latest Campanian. Broinsonia verecundia has lower abundances but is consistently present throughout the Campanian. Therefore, the top of B. signata and top and base of $B$. verecundia could be of potential stratigraphic significance in the area if correlated with existing global zonation schemes of nannofossils, i.e. the UC scheme (Burnett, 1998) and CC scheme (Sissingh, 1977; modified by Perch-Nielsen, 1985). Subspecies of $B$. parca also exist and are separated based on the classification of Wise (1983) into B. parca parca (plate width is $1-2 \times$ of the margin width; Plate 1 , figs. 7-8) and $B$. parca constricta (plate width is $<1 \times$ of the margin width; Plate 1, figs. 9-10). B. parca expansa (plate width is $>2 \times$ of the margin width) is absent in almost all samples. In this study, bases of the subspecies of B. parca parca and B. parca constricta have been recorded within the early Campanian, which agrees with the UC global zonation scheme of Burnett (1998).

Eiffellithus. Species of Eiffellithus represent a consistent component of the assemblage throughout the Fiqa Formation contributing $2 \%-8 \%$ up to $20 \%$ of the total abundance (Fig. 4). An influx and diversification of Eiffellithus are recorded within the Campanian of the section, including $E$. gorkae, E. turriseiffelii, E. parallelus, E. collis, E. angustus, E. perch-nielseniae, E. phantasma, E. nudus and E. lindiensis (Plate 5, figs. 2-42; Plate 6, figs. 1-9). The detailed subdivision of Eiffellithus species by Shamrock and Watkins (2009) is followed here in order to evaluate the potential significance of the genus for biozonation schemes. The species are assigned to two main groups based on the orientation of the cross-bars relative to the longitudinal axis of the coccolith: a group with axial crosses and a group with diagonal crosses. In the Fiqa Formation, medium to small species of diagonalcross forms like E. gorkae, E. casulus, E. parallelus and E. collis are more abundant than the larger species E. turriseiffelii and E. keio. Eiffellithus parallelus, E. turriseiffelii and
E. keio have distinctive cross-bars and could be easily differentiated; however, the smaller forms of E. gorkae, E. casulus and E. collis are tricky to separate. Eiffellithus collis is the smallest $(\leq 4 \mu \mathrm{m})$ with a distinctive elongate outline (Plate 6, figs. 4-9). Eiffellithus casulus has a very similar coccolith morphology to E. turriseiffelii but is smaller $(\leq 8 \mu \mathrm{m})$ (Plate 5, figs. 39-42). It is differentiated from E. gorkae by the constricted cross of the latter compared to the longer and more pointed cross of $E$. casulus. Species with intermediate orientation of the central cross $\left(20-44^{\circ}\right.$ orientation from the axial position, Shamrock and Watkins, 2009) like E. phantasma and E. perch-nielseniae are least abundant and are grouped into the diagonal-cross forms.

The main factor used to differentiate between the axialcross species is the size. Eiffellithus angustus is the largest and most bifurcate species with a size of $\geq 14 \mu \mathrm{m}$ (Plate 5, figs. 2-5). Eiffellithus eximius is less furcate with a size of $\geq 8 \mu \mathrm{m}$ (Plate 5, figs. 6-9). Eiffellithus nudus lacks distal bifurcation and is $\leq 7 \mu \mathrm{m}$ (Plate 5, figs. 10-11). It is also characterised by slightly oriented cross-bars within $20^{\circ}$ of the longitudinal axis, a feature that distinguishes it from other small axial-cross forms like E. lindiensis. In this study, all recorded $E$. lindiensis show an axially aligned cross with a size of $<4 \mu \mathrm{m}$ (Plate 5, figs. 12-15). Unlike other axial-cross forms, E. lindiensis is mostly present in the late Campanian to early Maastrichtian intervals.

Eiffellithus species with diagonal-cross forms are generally more common than the axial-cross forms in most intervals. The ratio between diagonal-cross and axial-cross forms is plotted in Fig. 4. It shows the dominance of axial-cross forms during the Coniacian and Santonian, which is mainly contributed by E. eximius (10\%-20\% of the total assemblage), followed by the dominance of diagonal-cross forms throughout most of the early Campanian.

Chiastozygus. Representatives of the genus Chiastozygus are typically low in abundance, generally $<3 \%$ of the total assemblage, but are consistently present throughout the Fiqa Formation, with minor peaks in the Campanian (Fig. 4). The most common species are $C$. synquadriperforatus and $C$. amphipons with sporadic occurrences of other species such as C. bifarius, C. trabalis and C. litterarius (Plate 4, figs. 2841). This genus is characterised by a simple rim and diagonal cross-bars, with species typically distinguished by the number of rim cycles (unicyclic vs. bicyclic) and the crossbar appearance (complexity and interference). Differentiation of Chiastozygus species can be difficult in the light microscope; the main distinguishing features are illustrated in Fig. 5. Species with unicyclic rims include $C$. amphipons, C. bifarius and C. litterarius. Chiastozygus amphipons has a relatively dark rim with very simple cross (Plate 4, figs. 28 29) similar to $C$. bifarius, but the latter is distinguished by a bright, birefringent cross (Plate 4, figs. 30-32). Chiastozygus litterarius can be distinguished from other unicyclic-rim species by the thick rim and a cross that is weakly birefringent (Plate 4, figs. 33-35). Chiastozygus trabalis could be 


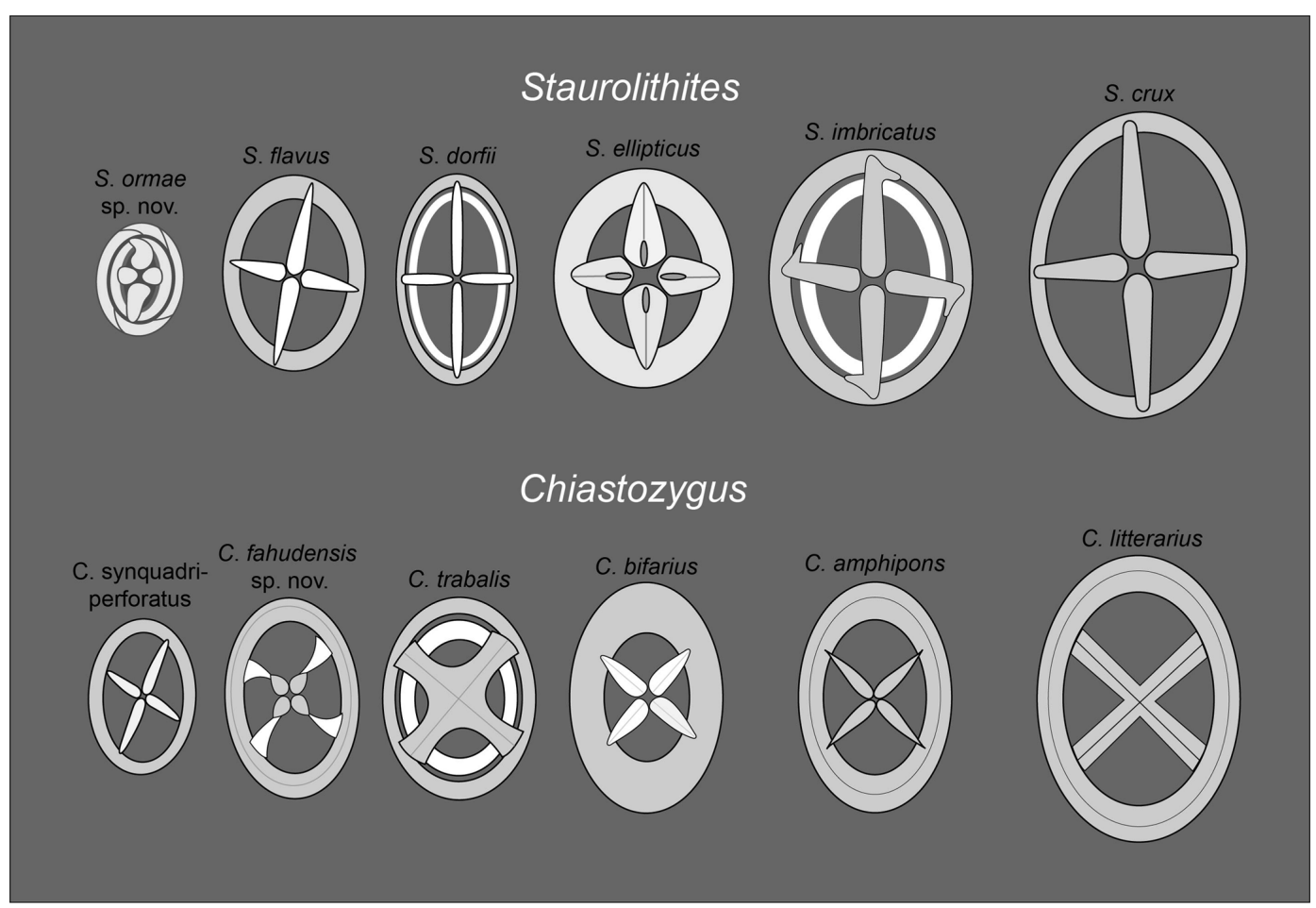

Figure 5. Characteristic features of the main species of Staurolithites and Chiastozygus under the light microscope compared to the new species $C$. fahudensis sp. nov. and $S$. ormae sp. nov.

easily identified by its bicyclic rim with a bright inner cycle and a complex cross (Plate 4, figs. 37-38). Chiastozygus synquadriperforatus is characterised by a smaller size than most of the other species and cross-bars with different sizes, with one bar being longer than the other (Plate 4, fig. 36). The new species, Chiastozygus fahudensis sp. nov., has a distinctive bright cross with a rosette-shaped central feature and indistinct rim (Plate 4, figs. 39-41). It occurs consistently throughout the section. A detailed description of the species is found within the systematic palaeontology section.

Staurolithites. Staurolithites species are found in Coniacian to Campanian samples but occur more frequently in the Campanian with an average abundance of $\sim 4 \%$ (Fig. 4). Representatives of this genus are characterised by a simple central axial cross, with species distinguished by their rim morphology (unicyclic vs. bicyclic) and the appearance of the central cross-bars. According to Perch-Nielsen (1985), there are many more species described in the original description of the group by Grun and Zweili (1980) than can be distinguished in the light microscope. Due to their limited stratigraphical significance, there are few studies that further discuss this group with species descriptions mostly based on scanning electron microscope images. This make species of Staurolithites difficult to separate under light microscope. The main distinguishing features under the light microscope for the most dominant species are illustrated in Fig. 5 and highlighted below.
Staurolithites crux is simply constructed with a unicyclic narrow rim and wide central area spanned by a simple cross (Plate 3, figs. 28-29). Staurolithites dorfii is narrowly elliptical, with a bicyclic rim. It has a distinctively bright cross and inner rim cycle (Plate 3, figs. 30-34). Staurolithites ellipticus is broadly elliptical with a thick cross that fills most of the central area (Plate 3, fig. 37). Staurolithites flavus is unicyclic and could be easily distinguished by its highly birefringent cross (Plate 3, figs. 35-36). Staurolithites imbricatus is characterised by its birefringent, bicyclic rim (Plate 3, figs. 38-40). The new species, Staurolithites ormae sp. nov., is characterised by its small size and bright, bicyclic rim. The central area is filled by a thick, birefringent cross that is slightly offset from the axial position (Plate 4, figs. 9-16). A detailed description of this species is found in the systematic palaeontology section.

\section{Discussion}

Through the Fiqa Formation, nannofossil assemblages show some distinct variations in species compositions. These variations are recorded in a lithology that is almost homogeneous. In this paper we focus on these nannofossil assemblage changes across the Fiqa Formation recovered from well $\mathrm{W}-4$. In this section, the most distinct abundance changes are discussed and compared to previous studies of Late Cretaceous nannofossil environmental preferences and responses 
to environmental change. The new data presented here provide important information on the palaeoenvironments of the Aruma Basin and help constrain the biogeographic distribution of key Cretaceous species.

\subsection{Palaeobiogeographic significance}

Here we investigate the abundances, within the Fiqa Formation, of Late Cretaceous taxa with known strong latitudinal controls on their biogeographic distributions (Fig. 6). Species that dominate nannofossil assemblages of the Fiqa Formation (Sect. 4.4.1) are generally typical of tropical Late Cretaceous Tethyan assemblages (e.g. Wagreich, 1992; Lees, 2007). For instance, relative abundances of $W$. barnesiae, in some intervals reaching more than $30 \%$, is similar to latest Campanian assemblages from Blake Nose (DSDP Site 390A; Linnert and Mutterlose, 2009b) and the Indian Ocean sites of Lees (2002). The other dominant group is made up of the cosmopolitan species of Prediscosphaera (Roth and Bowdler, 1981), which are present throughout the succession. The cosmopolitan species Cretarhabdus and Retecapsa (Roth and Bowdler, 1981), however, have generally low abundances, with Retecapsa becoming more frequent only within the early Campanian (Fig. 4). Discorhabdus ignotus is found to be common in the austral to temperate palaeobiogeographic zones of Lees (2002) but is also common to abundant in this tropical site (Fig. 6b). In the North Atlantic, D. ignotusis is relatively common in assemblages from the low-latitude Blake Nose (e.g. DSDP Site 390A; Linnert and Mutterlose, 2009b), but less abundant in samples from the Goban Spur (DSDP Site 549; Linnert et al., 2011) and North Sea area (e.g. Linnert et al., 2016). The consistent occurrence of Prolatipatella multicarinata in this study further supports its status as a tropical taxon (Lees, 2002, 2007). The relative rarity of Campanian Lucianorhabdus and Calculites obscurus within the Fiqa Formation assemblages compared to most Late Cretaceous successions, especially from high-latitude provinces (e.g. Thierstein, 1976; Wind, 1979; Lees, 2002), is also consistent with the observation of Lees (2007) that these are not tropical taxa. The observations of this study support the rare to absent status of the common and previously described higher-latitude, cooler-water taxa (Fig. 6a). The cool-water Repagulum parvidentatum (e.g. Wise, 1983, 1988; Crux, 1991; Street and Bown, 2000; Lees, 2002) is, as expected, absent from the assemblages of this study. Other higher-latitude species that are either absent or rare in the Fiqa Formation include the rare Ahmuellerella octoradiata and Gartnerago segmentatum (Wind, 1979; Thierstein, 1981), the extremely rare Kamptnerius magnificus, Reinhardtites anthophorus and Reinhardtites levis, and the absent Nephrolithus frequens (Lees, 2002), Seribiscutum primitivum (e.g. Roth and Bowdler, 1981; Crux, 1991; Street and Bown, 2000; Lees, 2002) and Crucibiscutum. The typically high-latitude species Arkhangelskiella cymbiformis (e.g. Wind, 1979; Thierstein, 1981) is very rare in the study area. The same is true for $B$. parca expansa, which is rarely recorded from the tropical palaeobiogeographic zone (Lees, 2002) and is absent from almost all samples from the Fiqa Formation. Marthasterites furcatus is commonly found in the austral palaeobiogeographic zone of Lees (2002) and is present in both the temperate and tropical zones; in the Fiqa Formation, M. furcatus is extremely rare. Ahmuellerella octoradiata, which was used by Lees (2002) as an indicator of cooling of surface water masses in the Late Cretaceous low-latitude oceans, shows two main peaks through the Fiqa Formation (Fig. 4). These peaks are usually correlated with increased abundances of Lithastrinus grillii (Fig. 4), which is also considered a potential temperate, "cooler" shelf taxon by Lees (2002). Helicolithus blairiae, which showed a potentially limited palaeogeographic range to the Western Interior Seaway of North America (Kita et al., 2016), is present in the Fiqa Formation. This observation provides a new insight into the geographical distribution of this rare Santonian species.

\subsection{Palaeoenvironmental significance}

Variation in nannofossil abundances and assemblage composition often reflects changes in the palaeoenvironmental conditions of ocean surface waters like nutrient supply, detrital input and surface water salinity (Mutterlose et al., 2005). One of the strongest assemblage changes recorded in W4 is an interval of very low Watznaueria barnesiae abundances within the early Campanian. This event occurs within a wider succession that hosts well-preserved and abundant nannofossil assemblages. Watznaueria barnesiae is one of the most robust nannofossil species of the Mesozoic and is often one of the few morphologies remaining in assemblages that have been subject to substantial dissolution (e.g. Roth and Bowdler, 1981). The dominance of W. barnesiae in Mesozoic nannofossil assemblages across a range of preservation states and locations, however, shows the wide ecological tolerance and biogeographic distribution of this species. The extent of this ecological range is illustrated in a study of Late Jurassic coccolith-rich laminae, which are interpreted to represent annual or seasonal blooms (Lees et al., 2006). Laminae with near mono-specific assemblages of W. barnesiae clearly show an ecological tolerance of this species to unusual conditions in the restricted Wessex Basin that exclude other taxa. This evidence suggests the need for caution when interpreting the relative abundance of $W$. banesiae as a palaeoenvironmental proxy, as this may reflect the relative increase or decrease in the abundance of other species, rather than a direct response of $W$. barnesiae to environmental change (Lees et al., 2005). It is, however, hard to explain the intervals of low W. barnesiae abundance in this record by simple dilution by other taxa, as it is actually dominant in intervals with the most diverse assemblages (see species richness, Fig. 4). Instead lower W. barnesiae abundances strongly correlate with more neritic conditions as independently determined from benthic microfossil assemblages (Fig. 7). The 

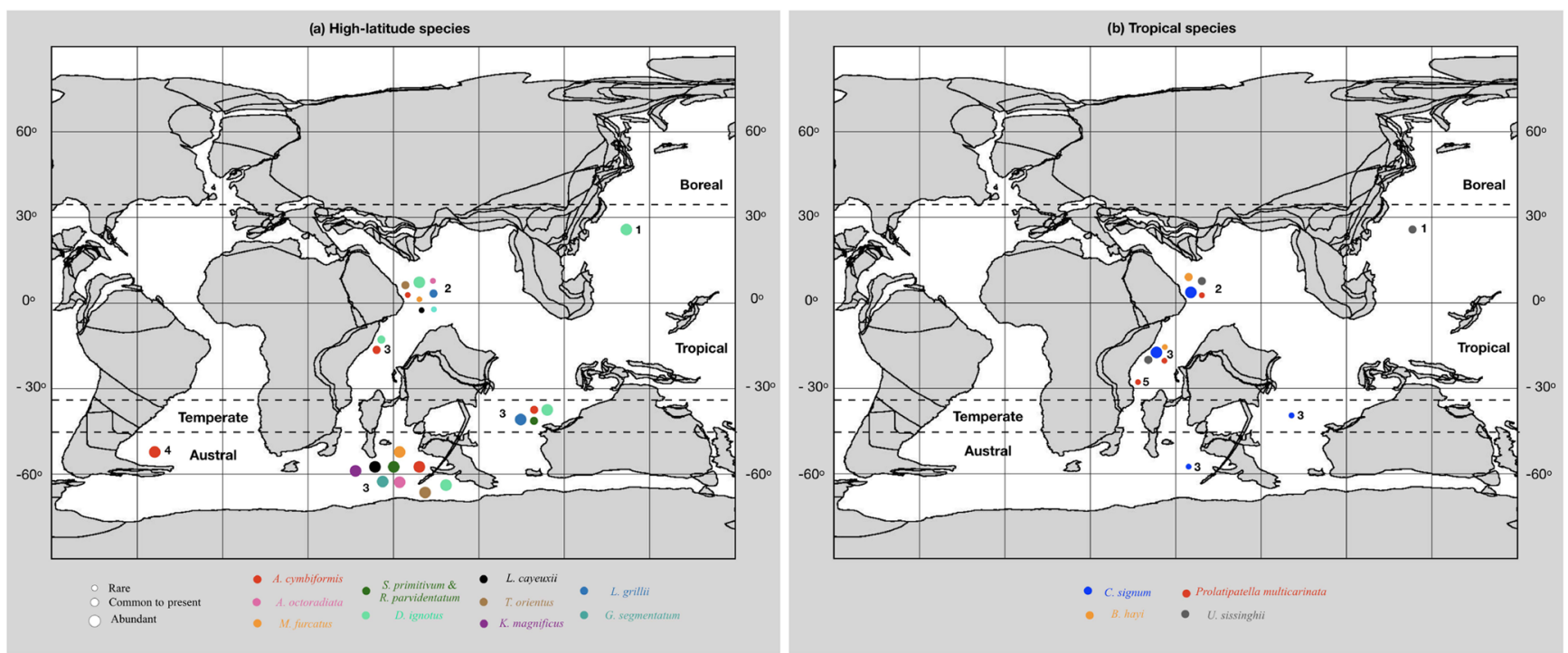

Figure 6. Distribution of selected (a) high-latitude and (b) tropical taxa compared to their status in the study area. Abundance data from (1) Lees and Bown (2005); (2) this study; (3) Lees (2002); (4) Therisin (1981); (5) Lees (2007). Palaeobiogeographic zones from Lees (2002) and Lees and Bown (2005). 75 Ma reconstruction map adapted from the PALEOMAP project (http://www.odsn.de/odsn/services/paleomap/ paleomap.html, last access: July 2018).

interval of low Watznaueria barnesiae is also characterised by elevated abundances of Biscutum constans and Zeugrhabdotus erectus with peaks of Discorhabdus ignotus and Corollithion signum. It succeeds an interval of elevated abundance of Micula staurophora. This interval is also correlated with a high abundance of Prediscosphaera cretacea, with a $W$. barnesiae to $P$. cretacea ratio falling from $>0.5$ to $<0.2$ (Fig. 7). As noted above, these intervals of low and extremely low W. barnesiae within the Fiqa Formation occur where microfossil association data (unpublished PDO microfossil data) indicate a shallower shelf environment (Fig. 7). This shallower setting is also supported by the consistent presence of "nearshore" and continental margin taxa such as Broinsonia spp. (Roth and Bowdler, 1981), Nannoconus spp. and Braarudosphaera spp. (Roth and Bowdler, 1981; Wyton and Bown, 2007). This link between low Watznaueria abundance and the development of neritic conditions is compelling, with Watznaueria abundance always high in intervals of increased water depth in the formation, which agrees with Atlantic shelf-to-ocean transects from the mid-Cretaceous (Roth and Bowdler, 1981). However, intervals of relatively reduced water depths are not always marked by lower abundances of $W$. barnesiae. For example, the W. barnesiae to P. cretacea ratio still fluctuates within the shallow water intervals and can reach 0.5 and rarely up to 0.8 . In the Indian Ocean, $W$. barnesiae has been previously found to be abundant in both shelf and open-ocean locations in Lees (2002). Together this indicates that the dominant control on the $W$. barnesiae to $P$. cretacea ratio is not water depth per se, but rather other environmental factors, such as temperature (e.g. Bukry, 1973; Thierstein, 1981; Roth and Bowdler, 1981; Thierstein, 1981;
Shafik, 1990; Watkins et al., 1996; Lees, 2002) and nutrient status (e.g. Erba et al., 1992; Williams and Bralower, 1995; Fisher and Hay, 1999), which are often coupled to relative water depth but can vary independently. Even though the influence of temperature on abundances of $W$. barnesiae has been debated in several studies as mentioned previously, the Aruma Basin is a tropical location close to the Equator where temperature fluctuations are likely to be small, even through a generally cooling Late Cretaceous climate (see Sect. 1). This is supported by the presence of characteristic tropical nannofossil assemblages throughout the formation and the lack of high-latitude taxa as discussed in Sect. 5.1. In contrast, factors associated with the well-documented tectonically active status of the basin (see Sect. 2) and the sea level change as shown from the study data are more compelling (Fig. 7). Watznaueria barnesiae has been linked to oligotrophic surface water conditions by Roth and Bowdler (1981) based on its low abundances in mid-Cretaceous palaeo-upwelling locations, with many subsequent studies showing similar trends (e.g. Erba et al., 1992; Williams and Bralower, 1995; Fisher and Hay, 1999). This link is further supported by the inverse correlation of $W$. barnesiae with high fertility indices that has been widely recorded in different locations (e.g. Roth, 1981; Roth and Bowdler, 1981; Erba, 1992, 2004; Erba et al., 1992; Williams and Bralower, 1995; Fisher and Hay, 1999; Street and Bown, 2000).

The most widely used taxa with high surface water fertility are Biscutum constans and Zeugrhabdotus erectus, an association that was first noted by Roth (1981). The higher nutrient preference of these taxa is supported by their cooccurrence with other indicators of high fertility and their 


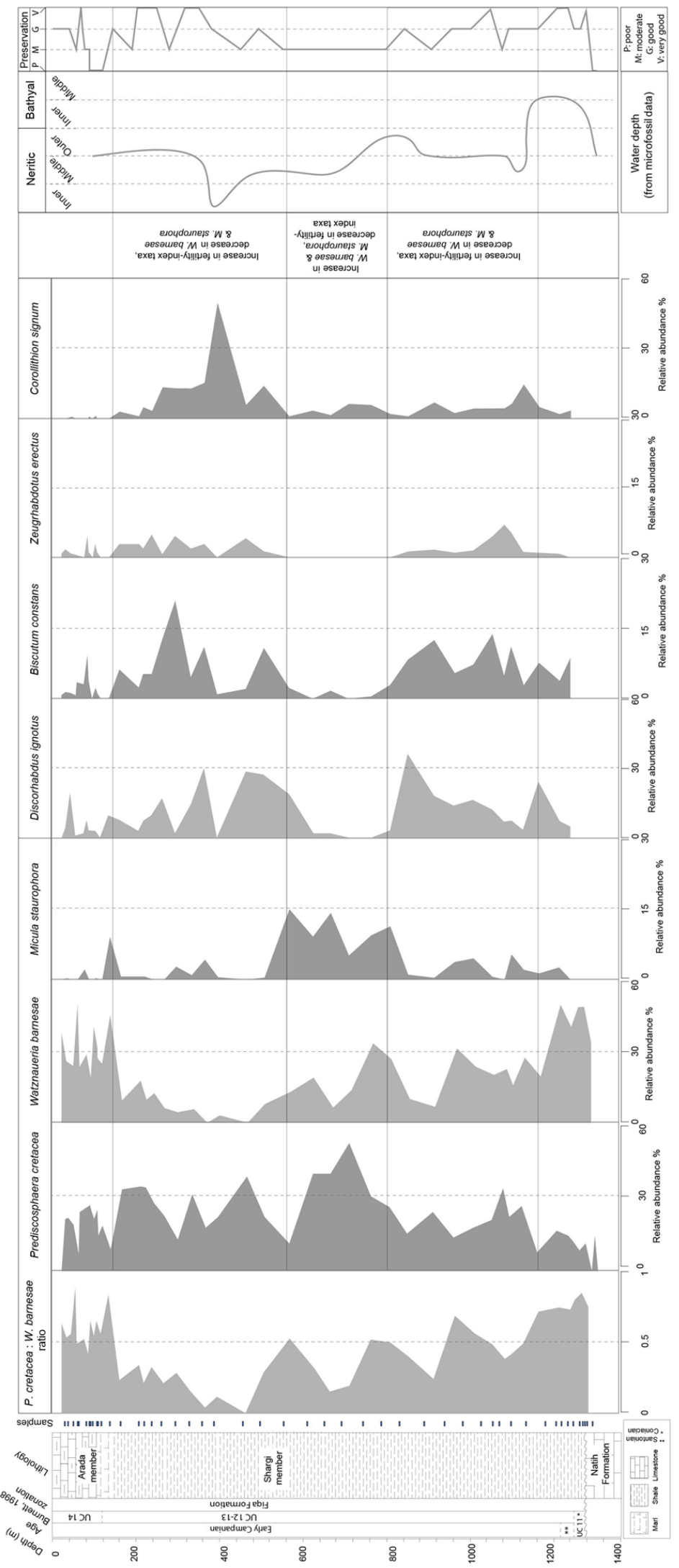

Figure 7. Changing abundance patterns of proxy marker taxa in the W-4, integrated with Ca\% and palaeoenvironment. 
peaks in intervals of high surface water productivity during the mid-Cretaceous (e.g. Erba, 1992; Mutterlose et al., 2005). Lees et al. (2005) argued that discrepancies in the distribution of these species, and a potential lack of taxonomic refinement, could lead to erroneous palaeoenvironmental interpretations. It is also suggested that $B$. constans is only abundant in high latitudes during the Late Cretaceous when $Z$. erectus remains generally rare in such locations (Thierstein, 1981; Lees, 2002). This is true for the study area as the relative abundance of these species is generally low $(<8 \%$ for $Z$. erectus; $<20 \%$ for $B$. constans), but with elevated abundances of both taxa during the low W. barnesiae intervals (Fig. 7). Peaks of B. constans (10\%-20\%) are usually more prominent and more frequent than those in $Z$. erectus $(4 \%-$ $6 \%)$. This might reflect episodes of more mesotrophic than eutrophic environments based on the findings of Erba (1992) that noted an increased abundance of $B$. constans at lower levels of fertility relative to $Z$. erectus. Peaks of Prediscosphaera have also been associated with increased surface water productivity and mesotrophic conditions by several authors (Eleson and Bralower, 2005; Hardas and Mutterlose, 2007). Discorhabdus ignotus is another high-fertility-related taxon (Erba, 1992; Herrle, 2002; Herrle et al., 2003) that also has major abundance peaks during the intervals of low Watznaueria barnesiae abundance (Fig. 7). Discorhabdus ignotus peaks (10\%-30\%) start just before any drop in the abundance of Watznaueria barnesiae and prior to peaks of B. constans and $Z$. erectus. High variation in the abundance of $D$. ignotus might reflect relatively unstable trophic conditions in the basin. There are intervals during which this species rapidly fluctuates in abundance from $2 \%-3 \%$ to $>15 \%$. Moreover, a prominent abundance increase in Corollithion spp. - mainly represented by $C$. signum - coincides with the decrease in Watznaueria barnesiae abundance (Fig. 7). The onset of a peak in Corollithion is usually accompanied or followed by a minor increase in Biscutum constans. Peaks of Corollithion spp. are also associated with peaks of Discorhabdus ignotus. Due to its marked abundance increase from $<5 \%$ to $>40 \%$, which is correlated with elevated abundance of other fertility-index taxa, Corollithion spp. might also represent a potential fertility-related indicator. It is also worth noting a relative abundance increase in the nannolith species Micula staurophora (up to $15 \%$ ) prior to peaks of $C$. signum, which further supports the potential of this species as a proxy marker (see Lees et al., 2005). Therefore, the trends of low W. barnesiae and the associated increased abundances of Biscutum constans, Zeugrhabdotus erectus, Discorhabdus ignotus, Corollithion signum and Prediscosphaera cretacea might indicate episodes of increased nutrient supply to the basin corresponding to intervals of shallower shelf settings, which might in turn indicate episodes of increased detrital input into the basin. Overall, this study of the long-term calcareous nannofossil assemblage compositions within a basin subject to dynamic tectonics and relative sea level change provides a useful "natu- ral experiment" to test the sensitivity of nannofossil taxa to external environmental drivers. Given the persistent tropical palaeo-location of the study site, within a long-term greenhouse climate state, we propose that most of these observed changes represent responses to surface water nutrient status and/or salinity and turbidity tolerances as shoreline proximity changes through time.

\section{Conclusions}

The calcareous nannofossil assemblages from the Late Cretaceous Aruma Basin are well-preserved, abundant and diverse, allowing for a detailed and improved taxonomic description of some poorly documented and/or described Cretaceous species and the identification of two new species. Staurolithites, Chiastozygus and Eiffellithus, a significant component of the formation, are described in detail and their problematic taxonomy is discussed. A detailed description of other main groups encountered in the studied section and the community change through time provided valuable information for palaeoenvironment and biostratigraphy. The assemblages also provided valuable environmental proxy data. Changes in the abundance of Biscutum constans, Zeugrhabdotus erectus, Discorhabdus ignotus and Corollithion signum in relation to Watznaueria barnesiae suggested episodes of elevated productivity during the neriticdominated basin of the Campanian. With limited detailed work published on nannofossil taxonomy and biostratigraphy from the Late Cretaceous sequences in the Middle East, this study presents new data that can be integrated with future work to improve our understanding of the assemblage changes in this part of the Cretaceous oceans and to apply and improve the global zonation schemes for this location and time interval. The major assemblage changes and the inception and extinction of nannofossil events can help to improve the biostratigraphic dating and the understanding of the palaeogeographic setting, sea level change and the basin subsidence history when correlated with existing geological data on the basin.

\section{Systematic palaeontology}

Two new heterococcolith species, Staurolithites ormae sp. nov. and Chiastozygus fahudensis sp. nov., are discussed here. The species description follows the guidelines of Young et al. (1997) and the higher taxonomic classification is based on Bown and Young (1997). This section is followed by a species list for all taxa recorded in this study. Illustrations of the species are presented in Plates 1-11.

\section{Staurolithites ormae sp. nov.}

Plate 4, figs. 9-16. 

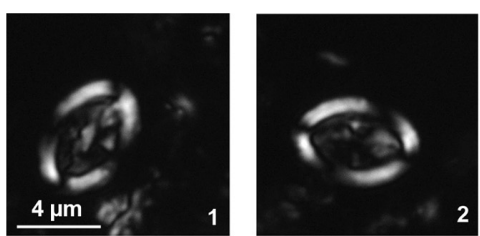

A. confusa W-3, 686

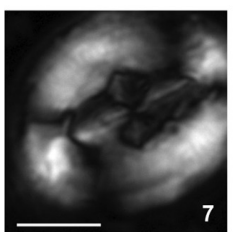

B. parca parca

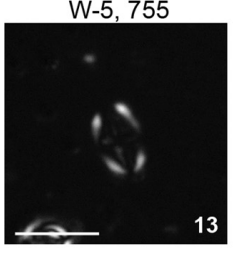

W-3, 76

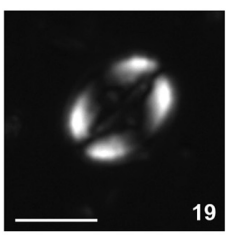

W-4, 344

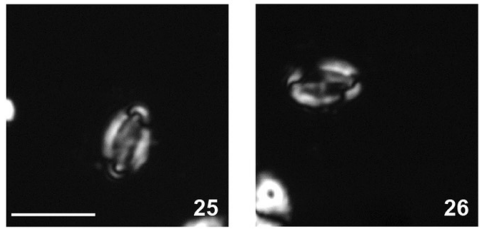

W-6, 969

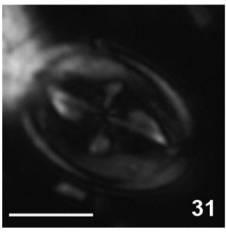

W-5, 750

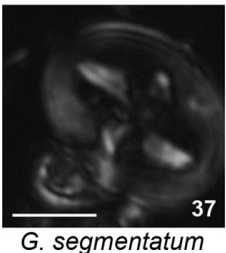

W-5, 750

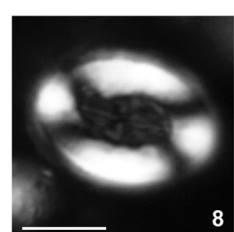

W-4, 111

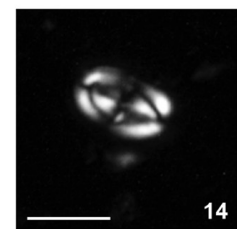

W-7, 700

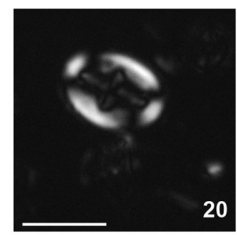

W-3, 686

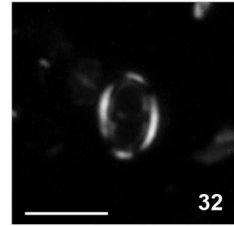

G. cf. ponticula W-7, 760

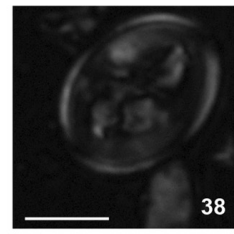

W-5, 750

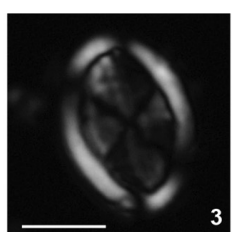

A. cymbiformis $\mathrm{W}-5,750$

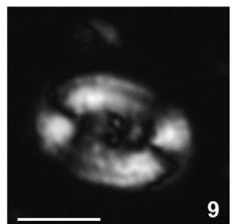

B. parca constricta $\mathrm{W}-3,3$

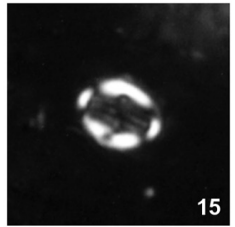

15

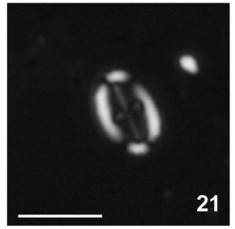

W-3, 686

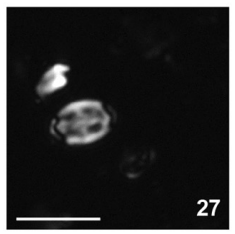

W-6, 969

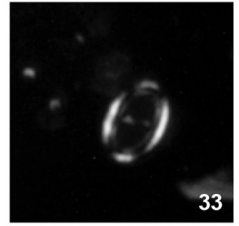

33

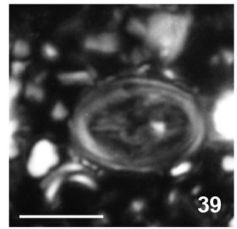

W-8, 672
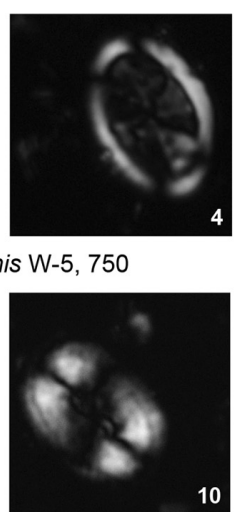

10

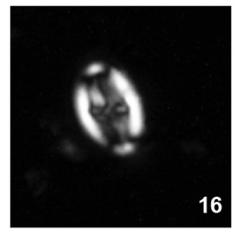

16

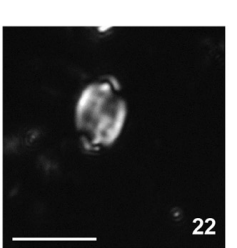

B. verecundia W-6, 997

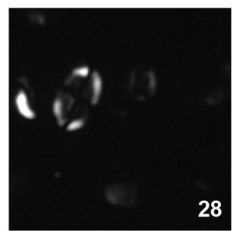

28

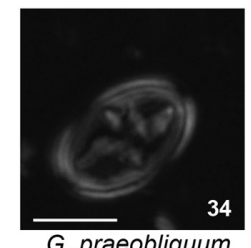

W-5, 755

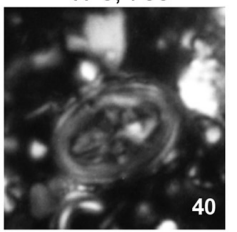

40

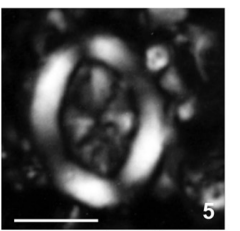

A. maastrichtiensis W-8, 681

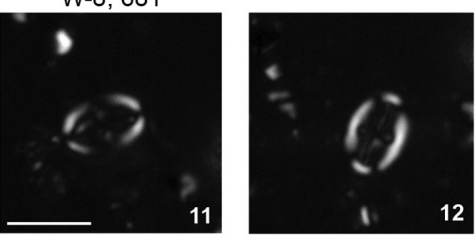

B. enormis W-3, 152

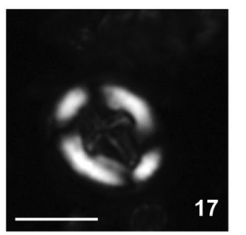

B. signata $\mathrm{W}-3,686$

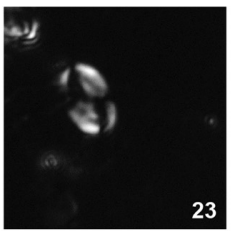

23
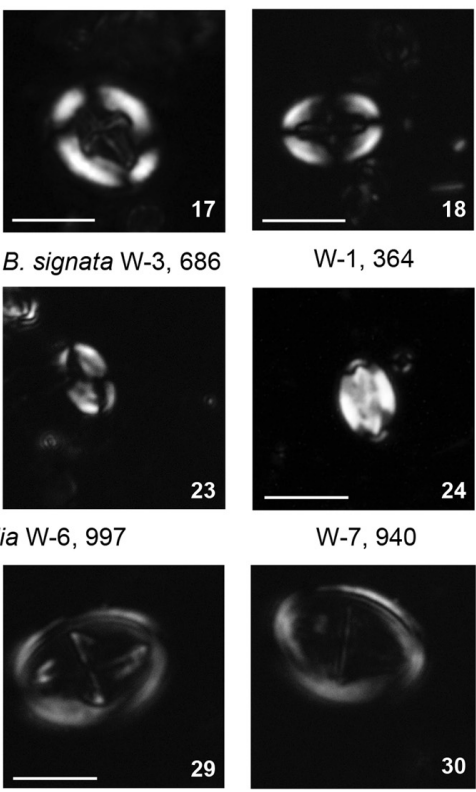

$\mathrm{W}-1,364$

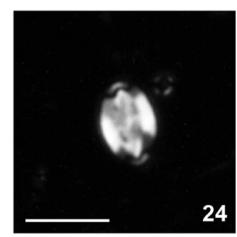

W-7, 940

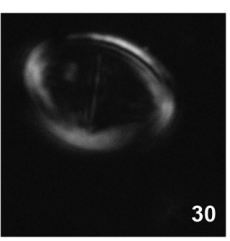

G. obliquum W-6, 1021

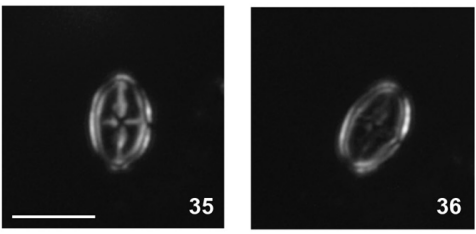

G. cf. praeobliquum W-6, 792.48

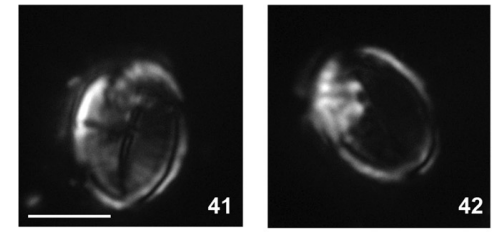

K. magnificus $\mathrm{W}-3,30$

Plate 1. Arkhangelskiales Arkhangelskiellaceae: Arkhangelskiella, Broinsonia Kamptneriaceae: Gartnerago, Kamptnerius. 


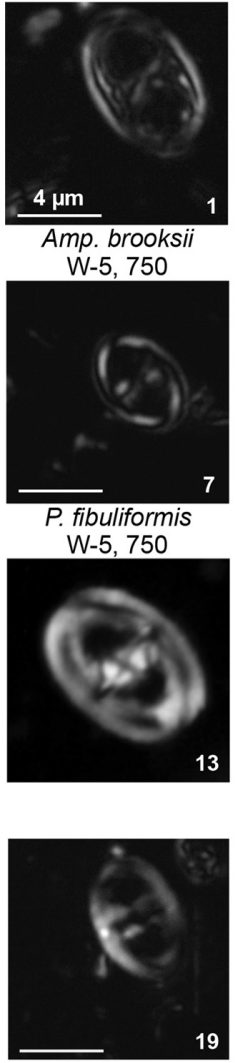

W-5, 755

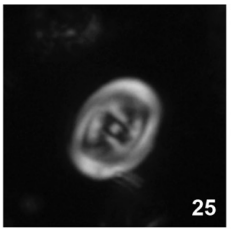

25
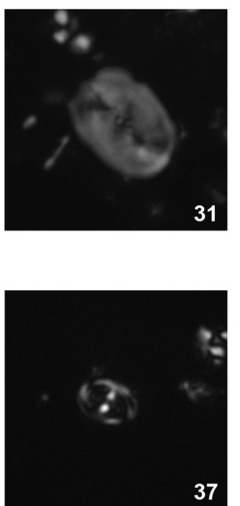

W-4, 248.4

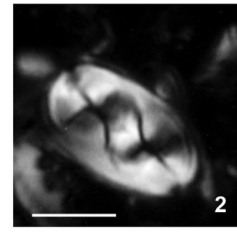

Gork. obliqueclausus W-8, 681

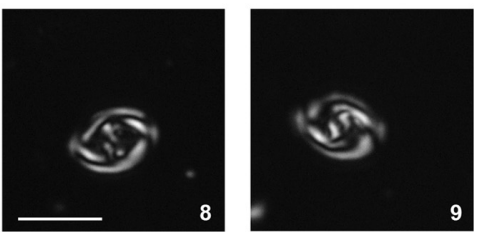

W-8, 672
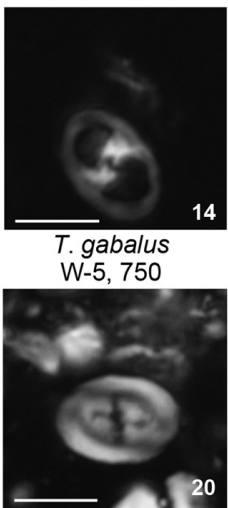

W-4, 90

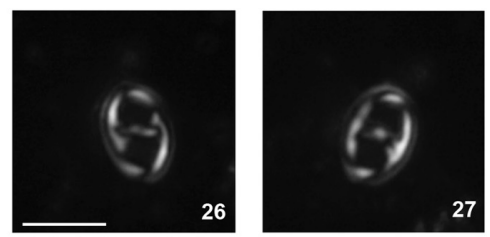

Z. acanthus W-4, 274.3

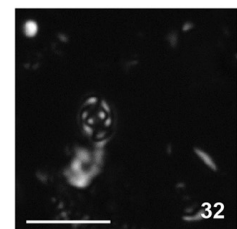

Z. clarus $\mathrm{W}-3,152$

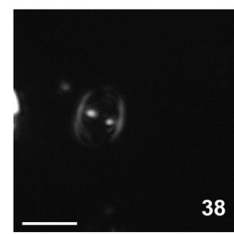

38

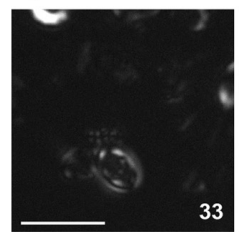

W-3, 624

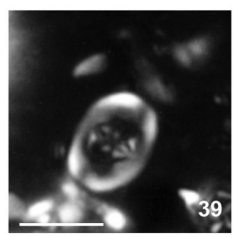

Z. howei, W-7, 970
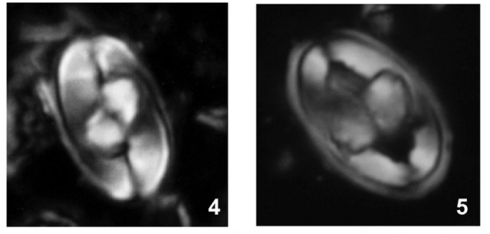

Gork. pseudanthophorus
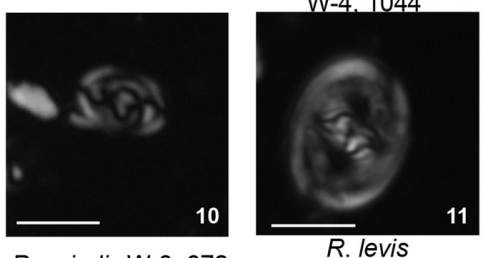

P. spiralis W-8, 672

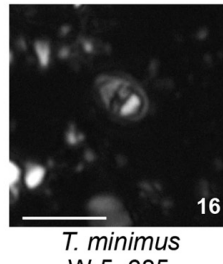

W-5, 685

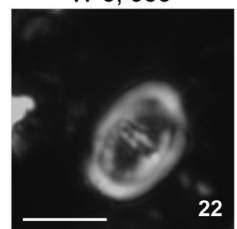

W-4, 1254.3

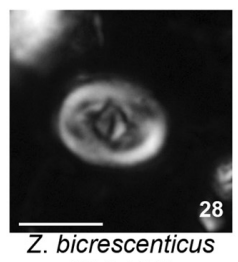

W-5, 755
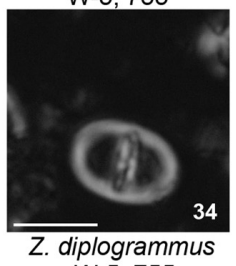

W-5, 755

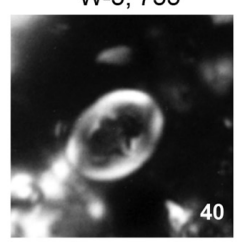

40

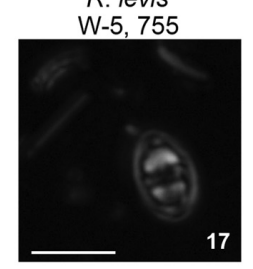

W-5, 755
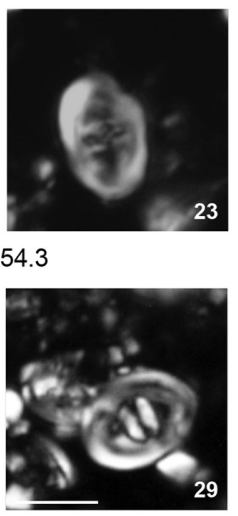

W-8, 672

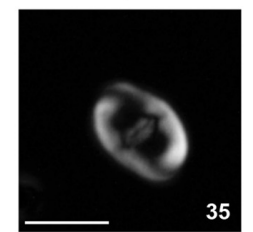

W-9, 541

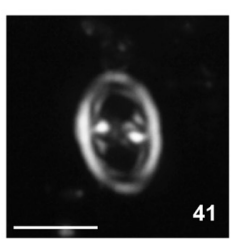

W-4, 248.4

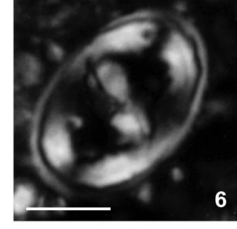

W-8, 672

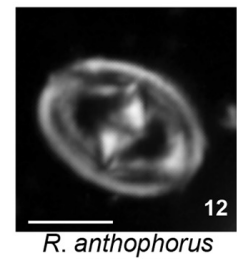

W-7, 620

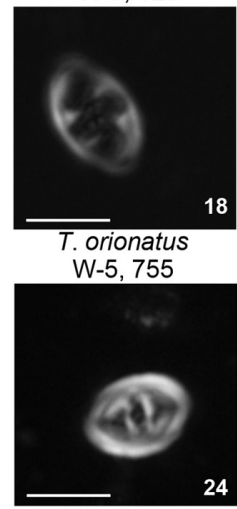

T. orionatus
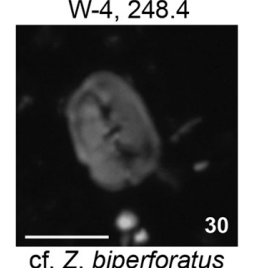

W-1, 518

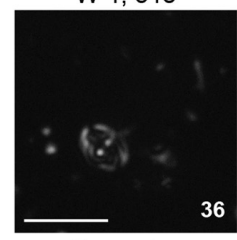

Z. erectus

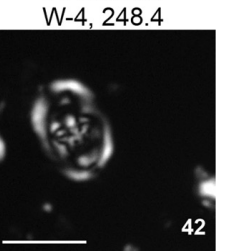

W-3, 3

Plate 2. Eiffellithales Chiastozygaceae: Amphizygus, Gorkaea, Placozygus, Reinhardtites, Tranolithus, Zeugrhabdotus. 

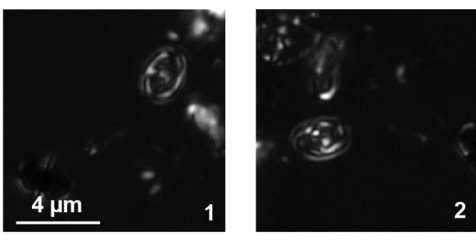

Z. noeliae $\mathrm{W}-3,76$

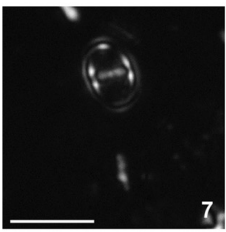

W-3, 152

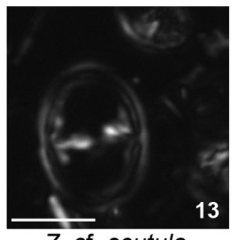

Z. cf. scutula

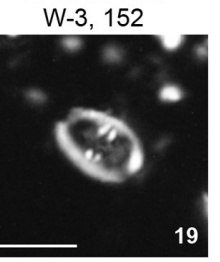

W-7, 1060

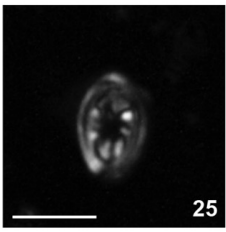

W-8, 843

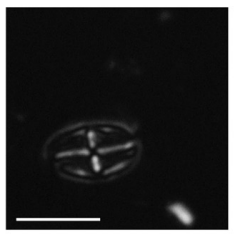

W-4, 168

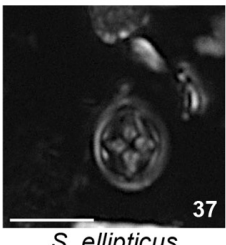

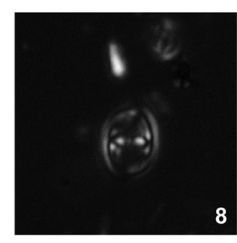

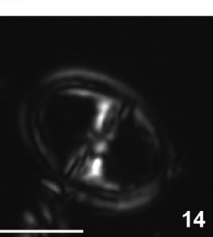

W-3, 305

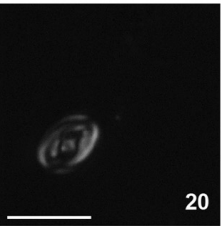

Z. sp. 1 W-6, 1021

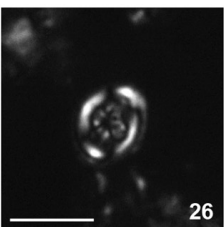

B. ambiguus $\mathrm{W}-3,488$
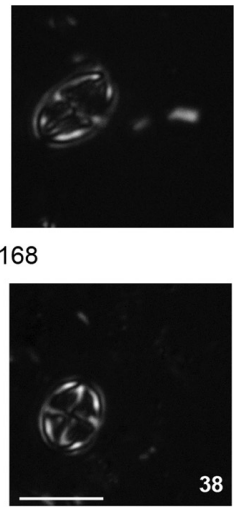

S. imbricatus W-3, 76

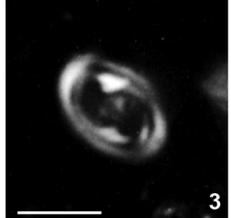

W-7, 1015

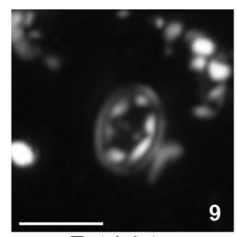

Z. trivictus

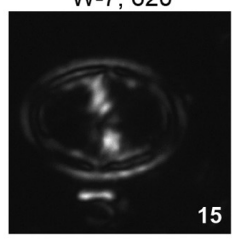

15
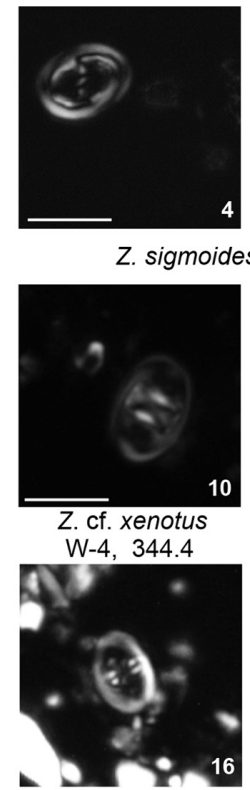

Z. sigmoides $\mathrm{W}-6,1021$
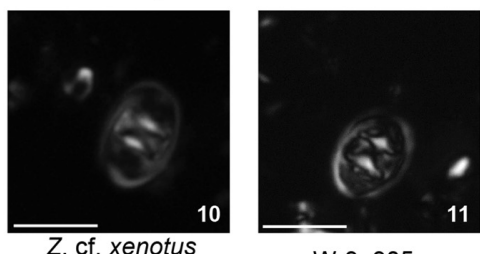

21
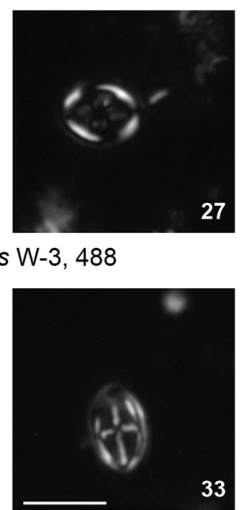

W-7, 970

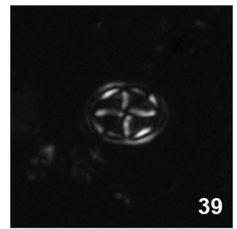

39
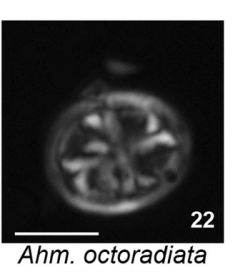
W-5, 755

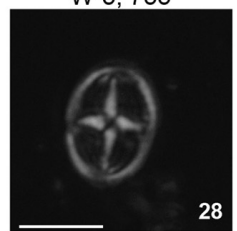

S. crux W-5, 755

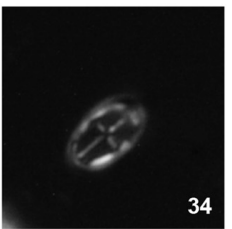

34

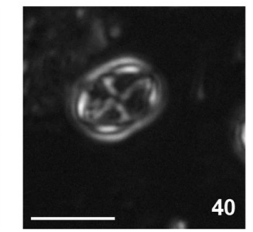

W-5, 755

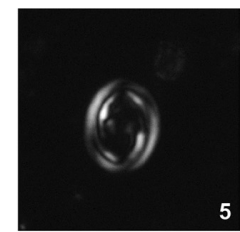

W-3, 305

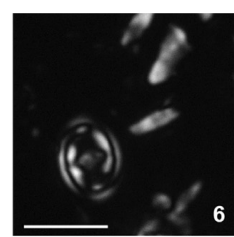

W-3, 152

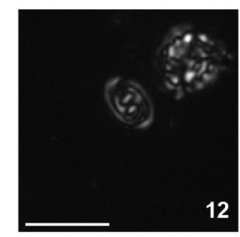

W- 3,488

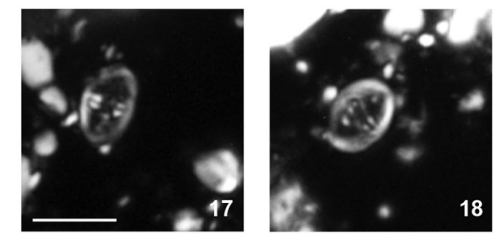

Z. cf. fissus W-7, 1060

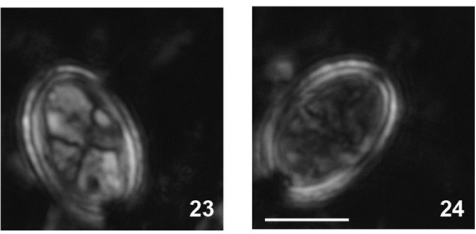

Ahm. regularis $\mathrm{W}-5,755$

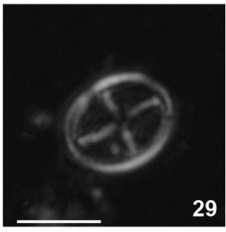

W-5, 755

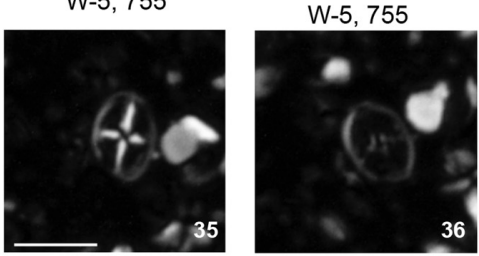

S.flavus W-8, 660

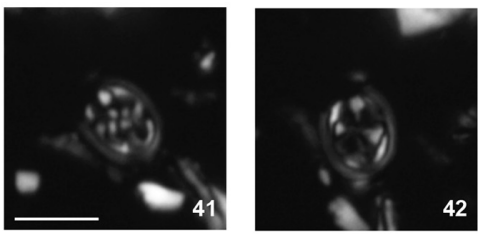

S. mielnicensis W-4, 90

Plate 3. Eiffellithales Chiastozygaceae: Zeugrhabdotus, Ahmuellerella, Bukrylithus, Staurolithites. 

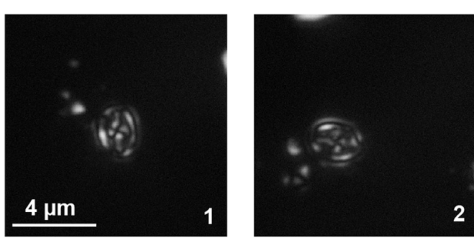

S. handleyi W-3, 30

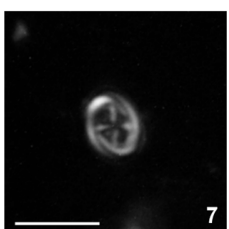

S. cf. laffittei $\mathrm{W}-7,730$

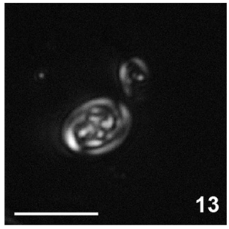

W-6, 969

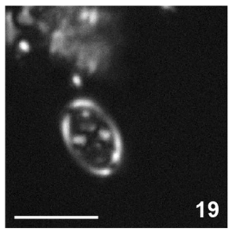

S. cf. ngurumahambaensis W-3, 594

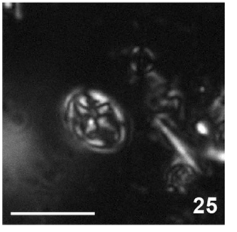

W-3, 76

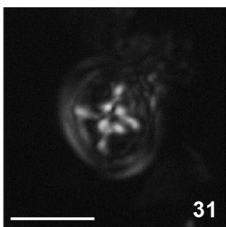

W-3, 305

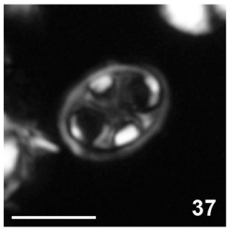

C. trabalis W-4, 168

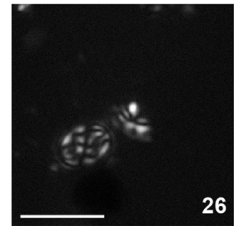

W-3, 15

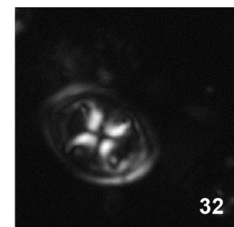

32

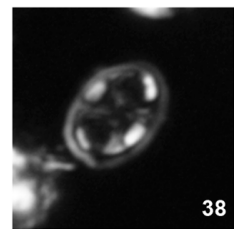

38

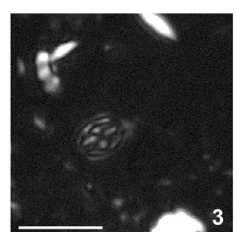

S. handleyi W-3, 152

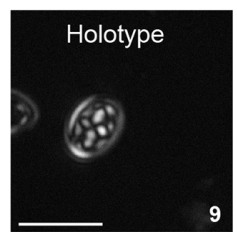

S. ourmae sp. nov. W-6, 969

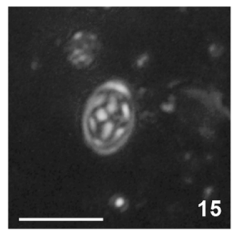

W-4, 248.4

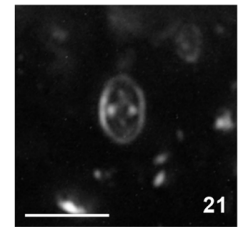

W-7, 760

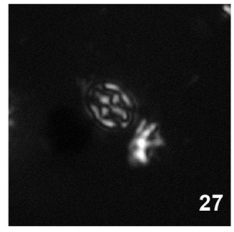

27
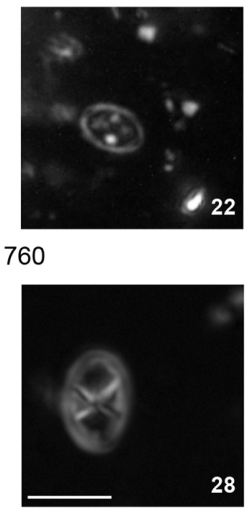

C. amphipons W- 5,755

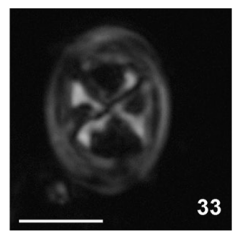

C. litterarius

W-4, 274

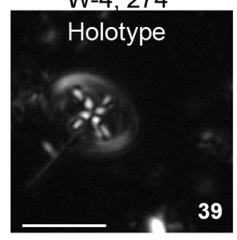

C. fahudensis sp. nov. W-3, 152

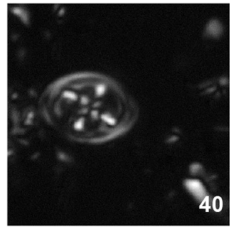

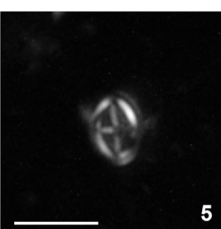

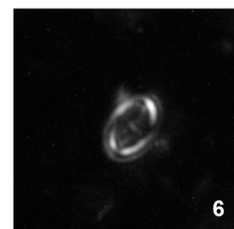

S. cf. handleyi W-7, 910

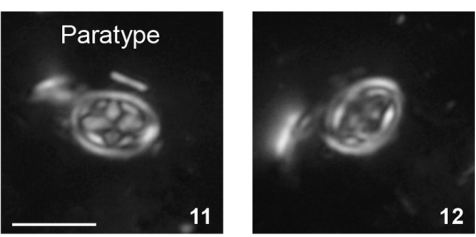

W-4, 248.4

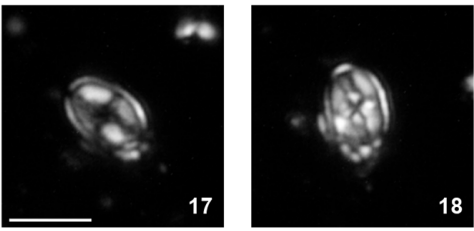

S. cf. elongatus W-7, 640

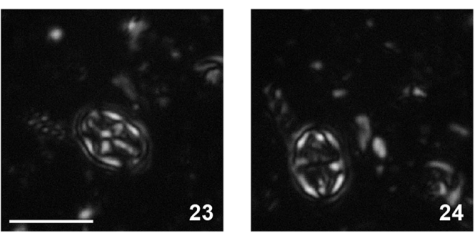

S. zoensis W-3, 152

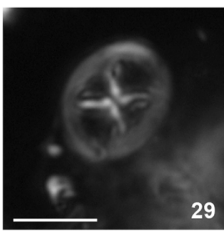

W-5, 755

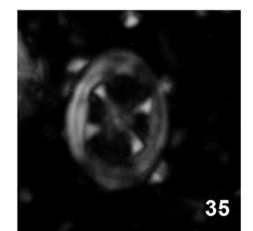

W-8, 681

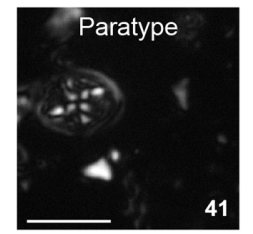

W-3, 476

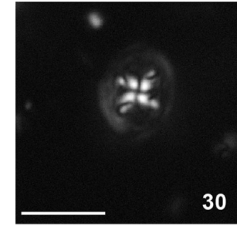

C. bifarius $\mathrm{W}-3,30$

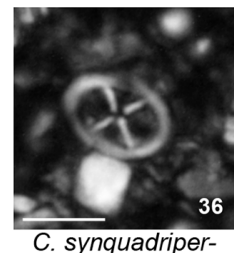

foratus W-8, 681

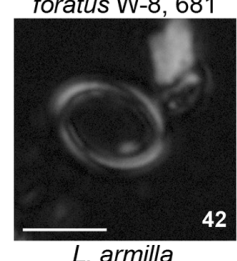

Plate 4. Eiffellithales Chiastozygaceae: Staurolithites, Chiastozygus, Loxolithus. 


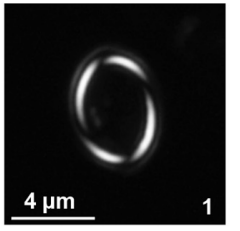

L. bicyclus
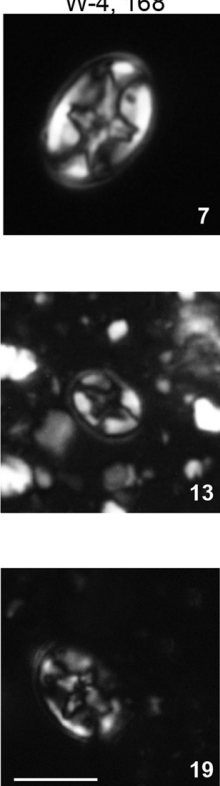

E. perch-nie/seniae W-3, 488

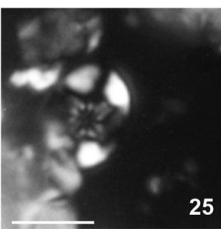

W-8, 588

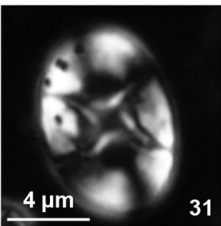

E. Keio W-4, 168

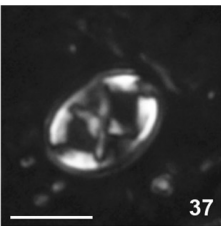

E. striatus W-4, 942
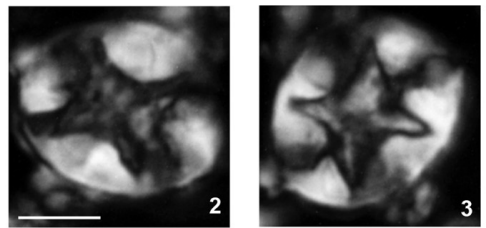

E. angustus W-8, 681

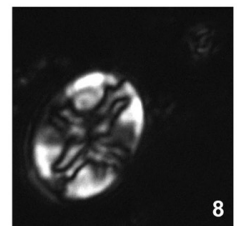

W-3, 76
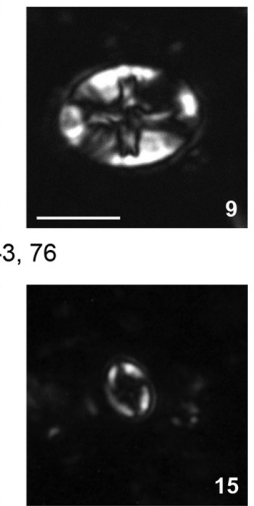

W-7, 790
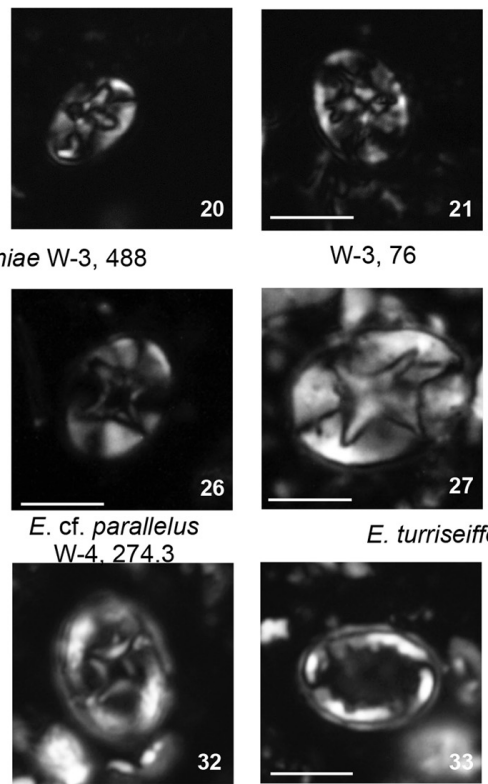

W-3, 76

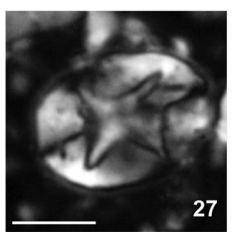

E. turriseiffelii W-8, 645

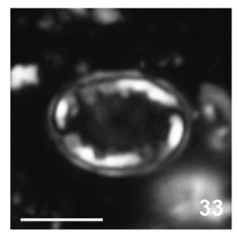

W-4, 63

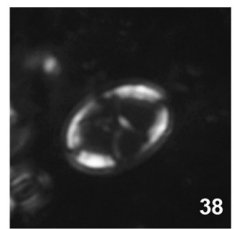

38

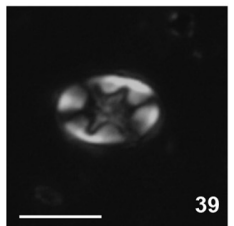

E. casulus W-4, 1325.9
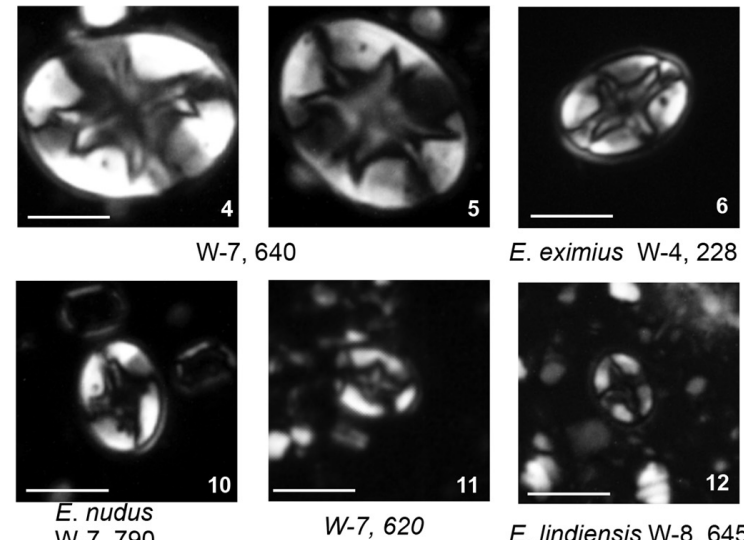

E. eximius $\mathrm{W}-4,228$

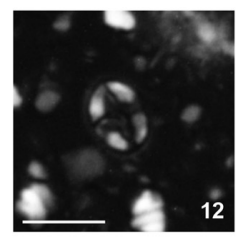

$W-7,620$
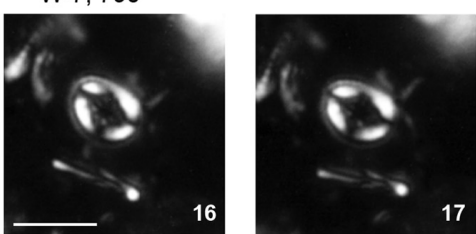

E. lindiensis W-8, 645

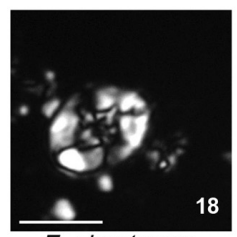

E. phantasma

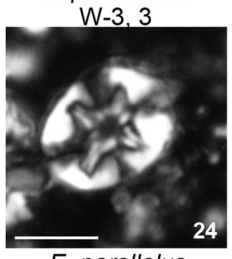

W-3, 76
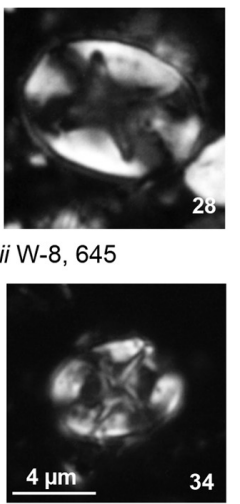

W-1, 942

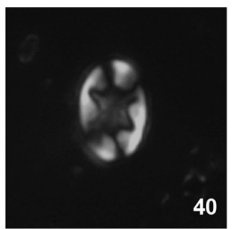

40
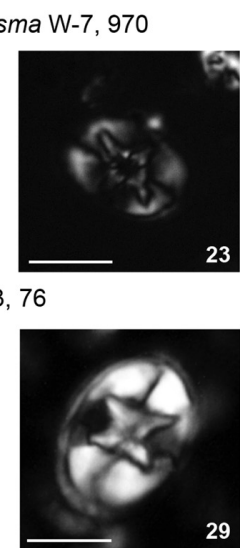

W-8, 660
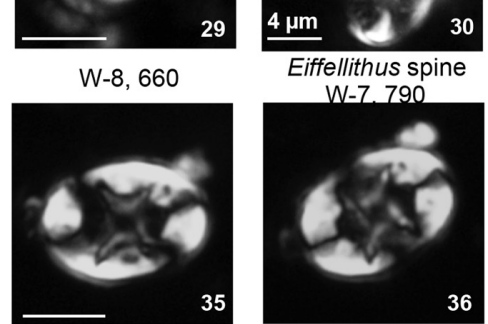

Eiffellithus spine

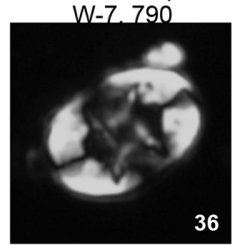

W-4, 168
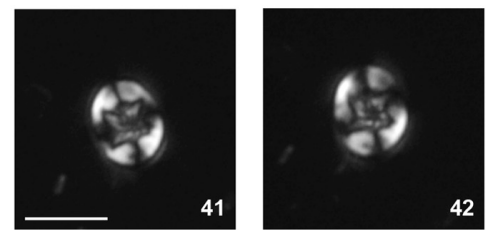

W-4, 1295.4

Plate 5. Eiffellithales Chiastozygaceae: Loxolithus Eiffellithaceae: Eiffellithus. 


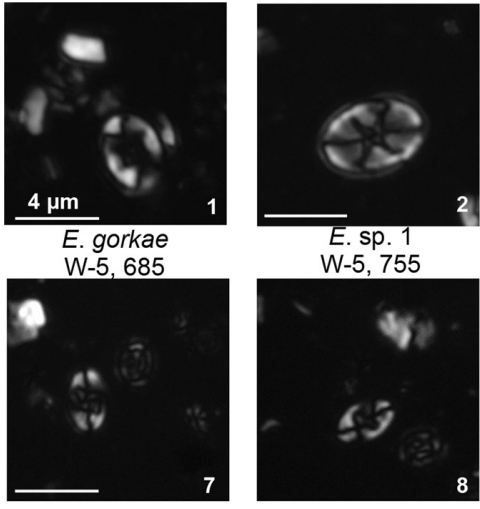

W-4, 216

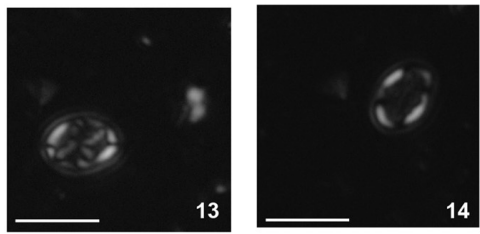

W-5, 755

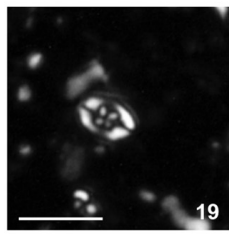

H. leckiei W-8, 660

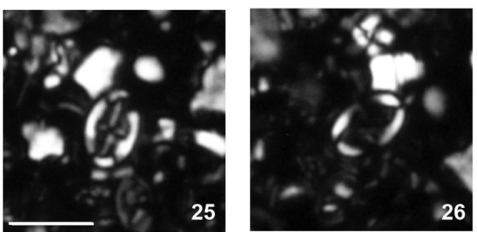

W-8, 672

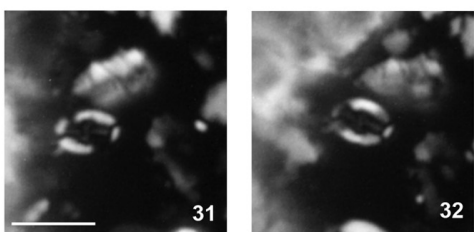

W-8, 588

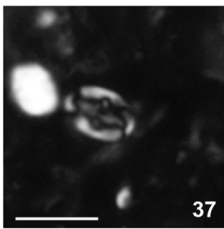

W-1, 882

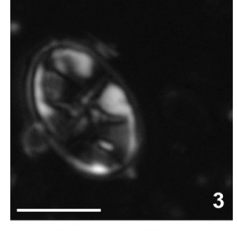

W- 5,755

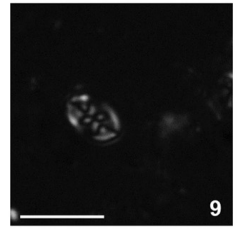

W-3, 76

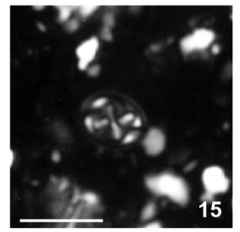

W-8, 660

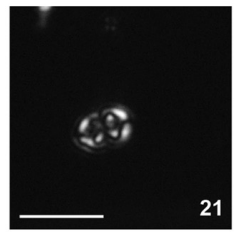

W-6, 969

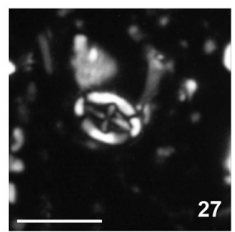

W-8, 645

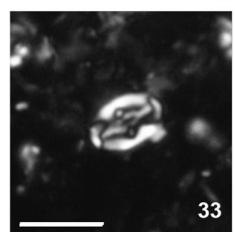

H. blairiae W-1, 860

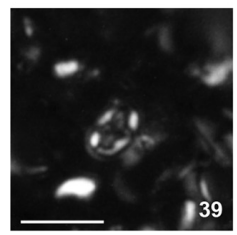

W-7, 1015

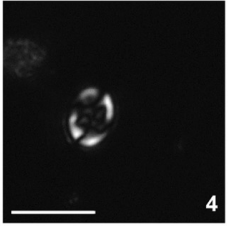

E. collis W-1, 682
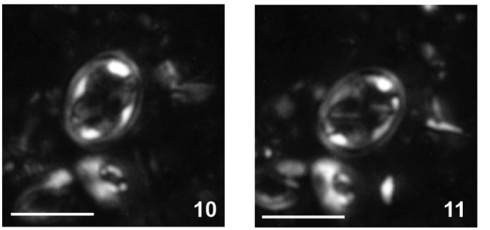

H. trabeculatus W-7, 1015
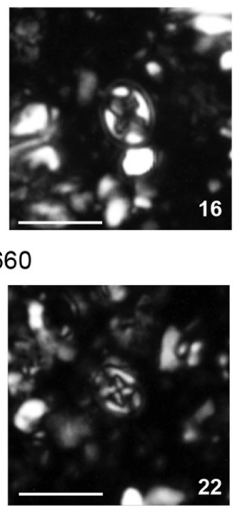

W-8, 672
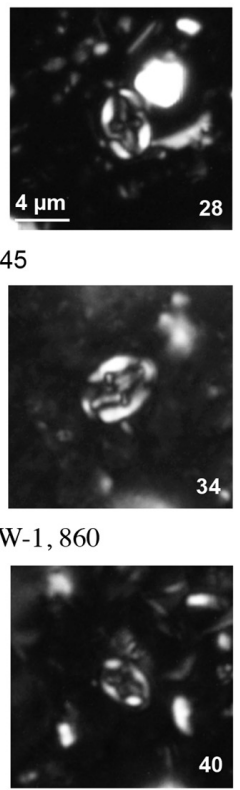

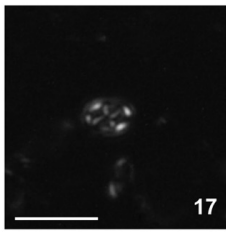

W-7, 970
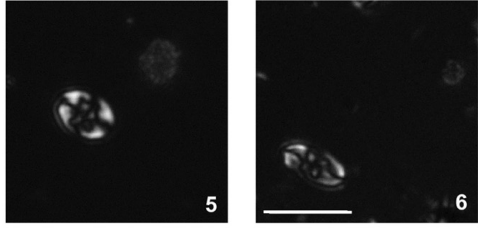

W-3, 76

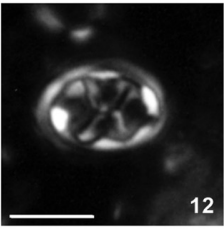

W-7, 1015
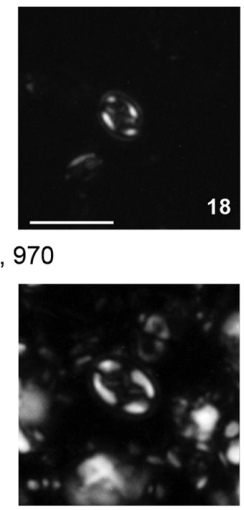

H. compactus W-8, 660

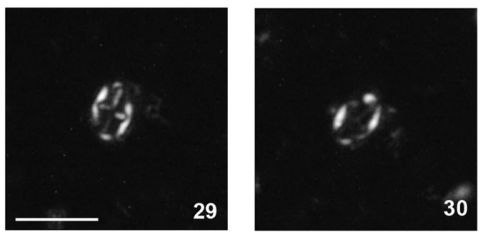

W-7, 970

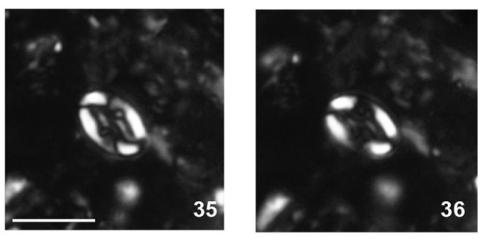

W-1, 860

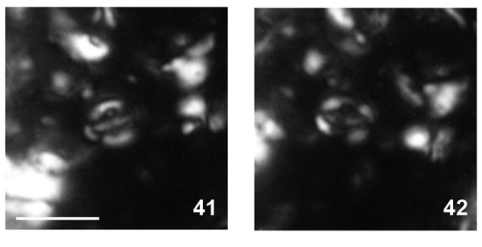

W-7, 1015

Plate 6. Eiffellithales Eiffellithaceae: Eiffellithus, Helicolithus. 


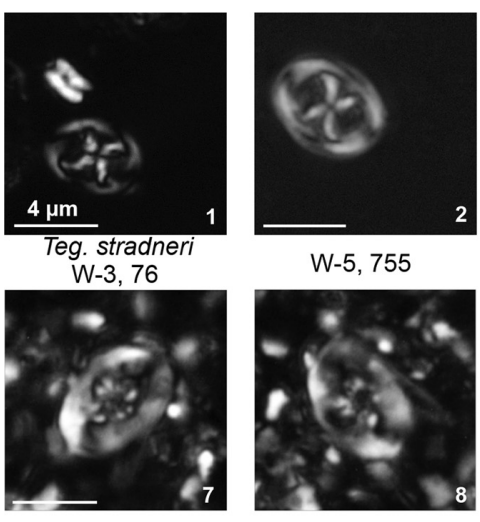

Rha. cf. achlyostaurion W-8, 681
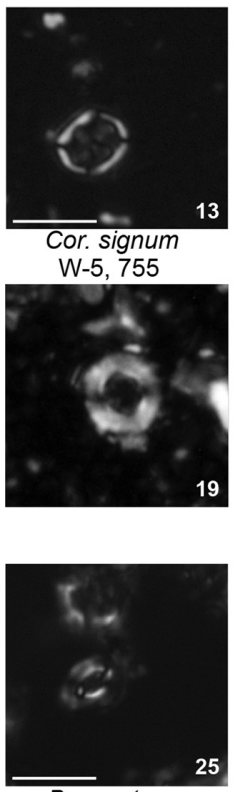

B. constans

W-3, 594

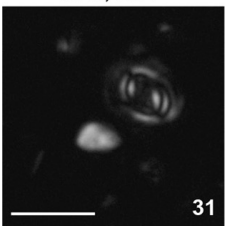

B. magnum W-3. 594

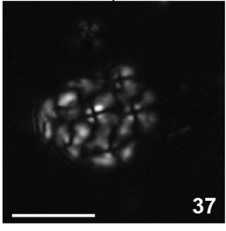

Disc. coccosphere W-6, 997

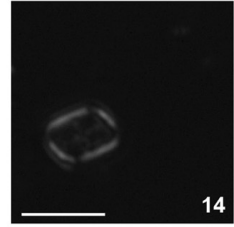

W-5, 755

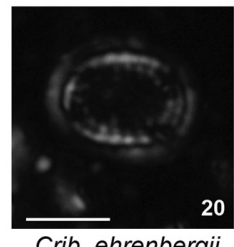

Crib. ehrenberg IBH-755

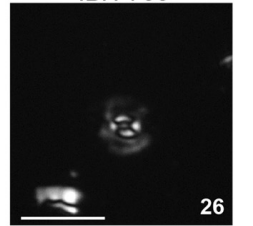

W-3, 76

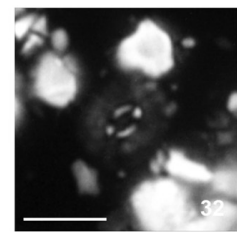

B. melaniae $\mathrm{W}-8,588$

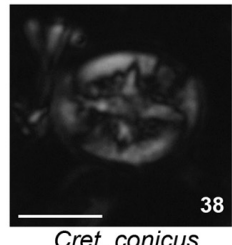

IBH-755

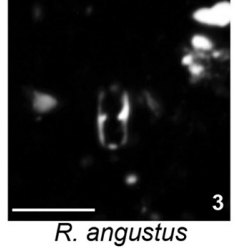

W-8, 843

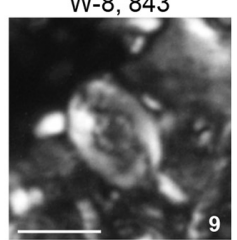

W-8, 68

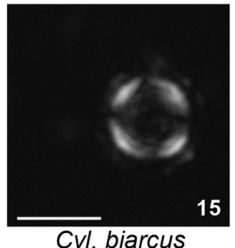

W- 5,755

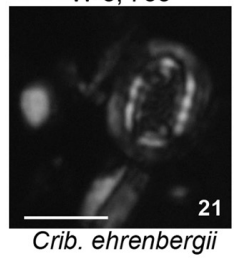

W-5, 755

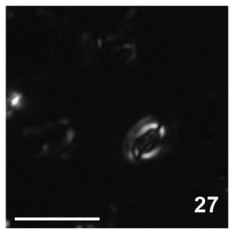

W-3, 76
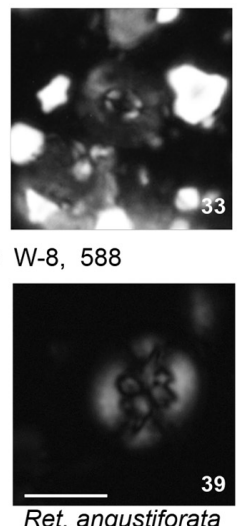

W-6, 1021
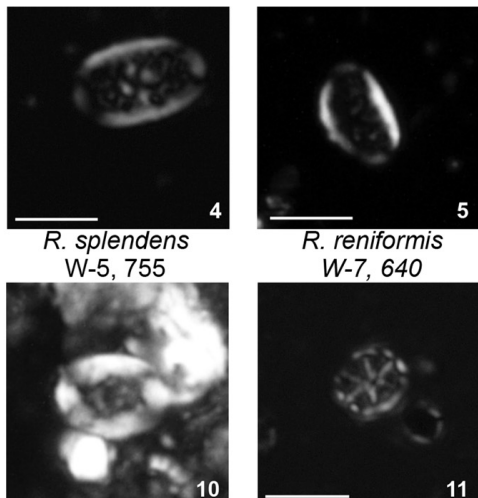

$W-7,640$

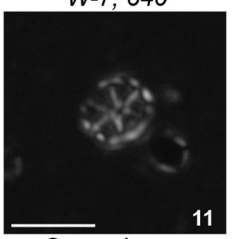

Cor. exiguum

W-5, 755

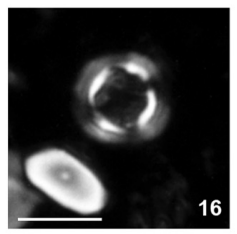

W-8, 843

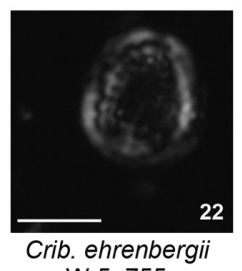

W-5, 755
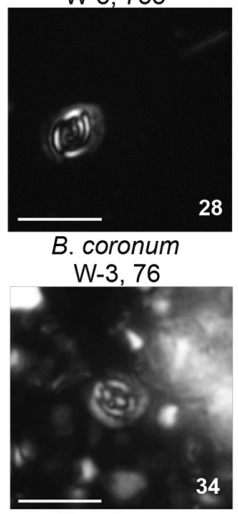

Crucib. spp. W-4. 63

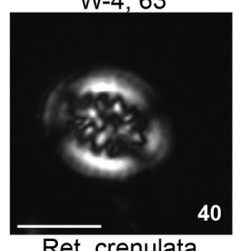

Ret. crenulata

W-6, 1021
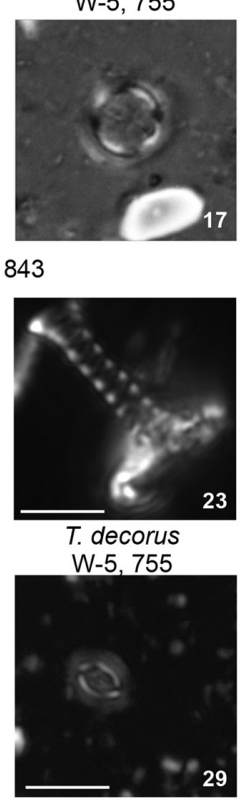

W-5, 685

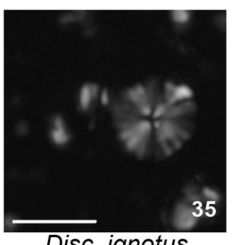

Disc. ignotus

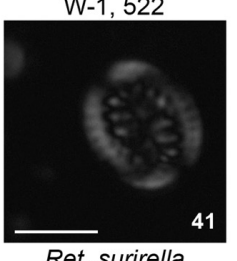

Ret. surirella

W-6, 1021

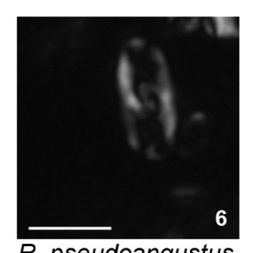

R. pseudoangustus

W-5. 755

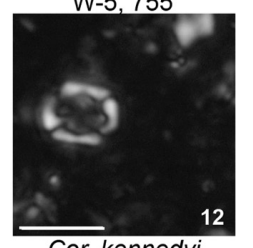

Cor. kennedy

W-5, 755

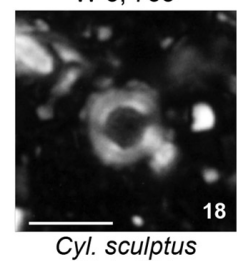

W-8, 681

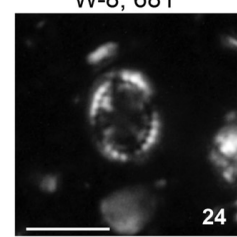

W-7, 1015
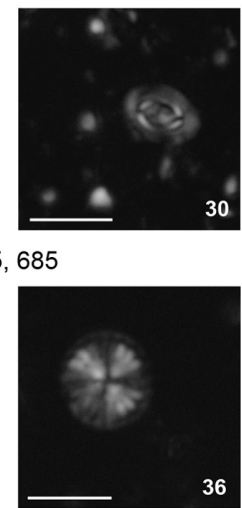

W-5, 755

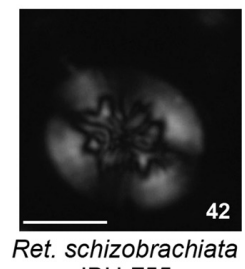

IBH-755

Plate 7. Eiffellithales Eiffellithaceae: Tegumentum; Rhagodiscaceae: Rhagodiscus. Stephanolithiales Stephanolithiaceae: Corollithion, Cylindralithus. Podorhabdales Axopodorhabdaceae: Cribrosphaerella, Tetrapodorhabdus; Biscutaceae: Biscutum, Discorhabdus; Cretarhabdaceae: Cretarhabdus, Retecapsa. 


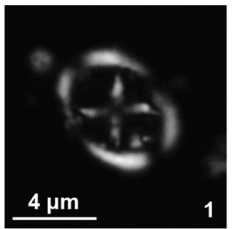

Grant. meddii

W-4 168

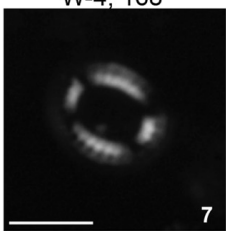

M. pemmatoidea $\mathrm{W}-4,168$

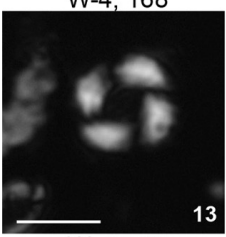

W. ovata W-5, 755

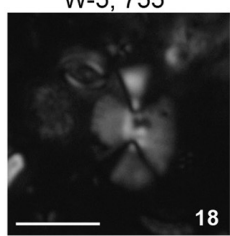

W. bayacki W-5, 755

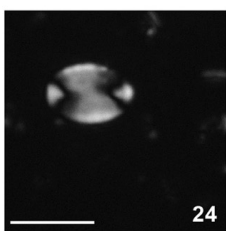

W-1, 882

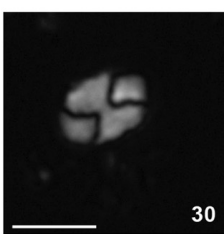

30

W-5, 755

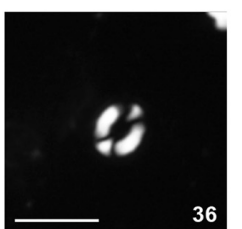

W-4, 274.32

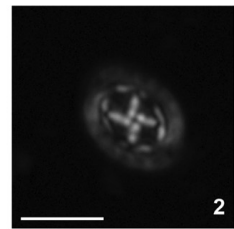

Pred. cretacea W-3, 305

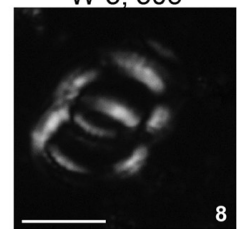

W-3, 351

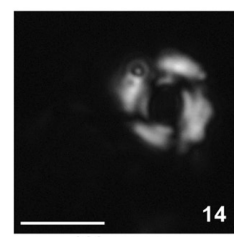

W. ovata

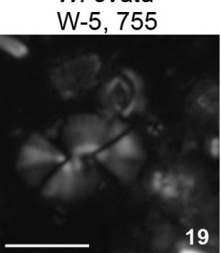

19

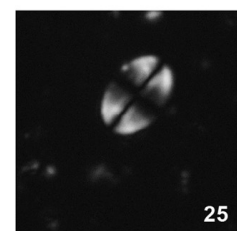

25

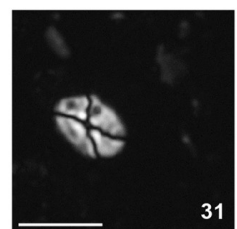

W-1, 392

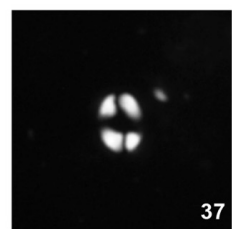

37

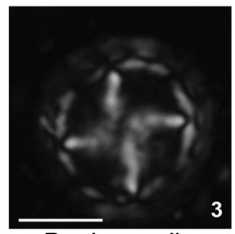

Pred. grandis

W-5. 755

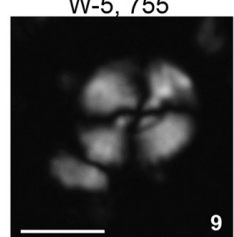

W. barnesiae W-5, 685
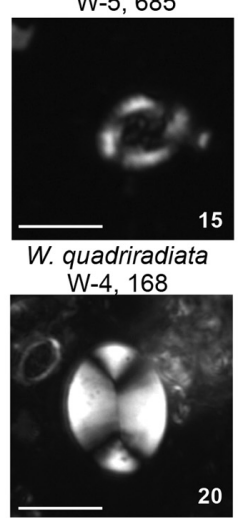

Pro. multicarinata W-5, 755

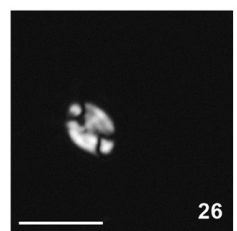

Calcu. obscurus W-6, 844

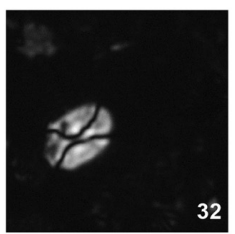

32

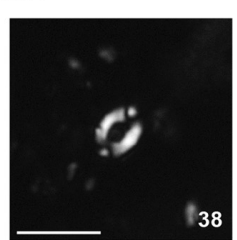

W-2, 2385.1
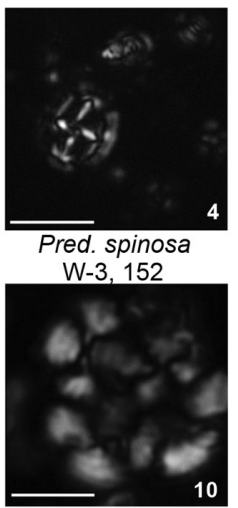

Watz. coccosphere W-5, 685

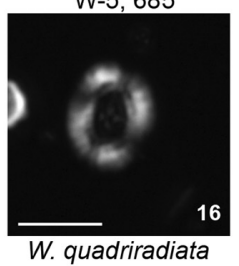

W-5, 755

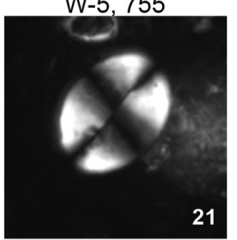

21
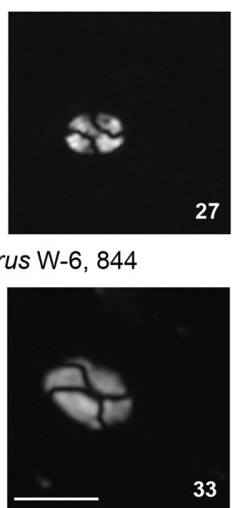

Calcu. ovalis

W-5, 755

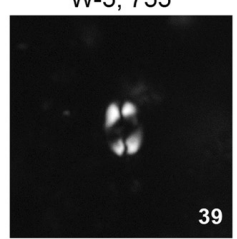

39

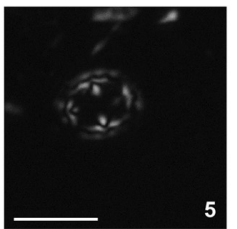

W-3, 305

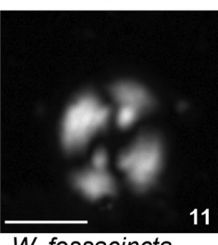

W. fossacincta

W-5, 755

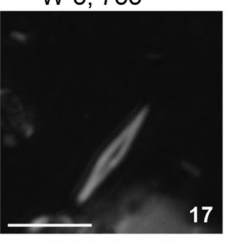

Calci. fossilis W-5, 755

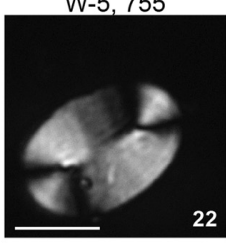

W-1, 882

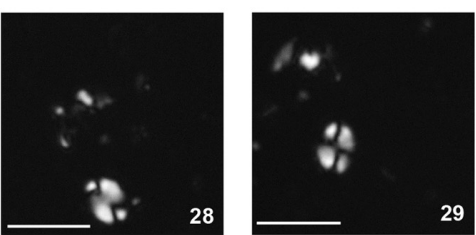

W-7, 970

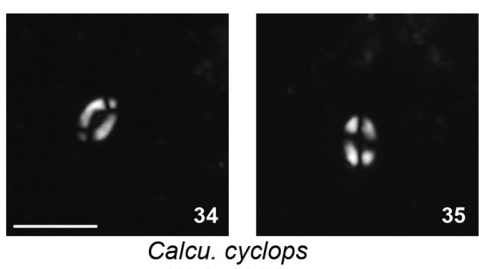
W-6, 1021

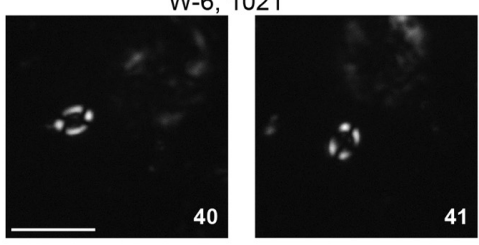

W-4 274.32

Plate 8. Podorhabdales Cretarhabdaceae: Grantarhabdus Prediscosphaeraceae: Prediscosphaera Tubodiscaceae: Manivitella; Watznaueriales Watznaueriaceae: Watznaueria; Syracosphaerales Calciosoleniaceae: Calciosolenia; heterococcoliths inc sedis placoliths inc sedis: Prolatipatella; holococcoliths common genera: Calculites. 


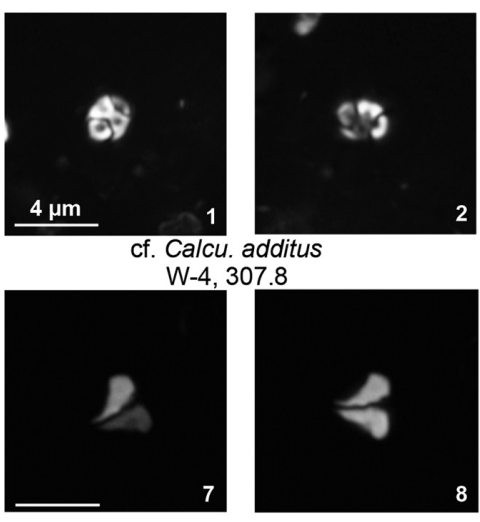

W-4, 344.4

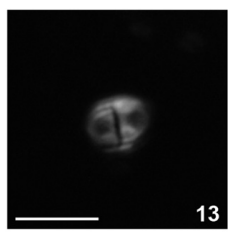

W-4, 1295.4

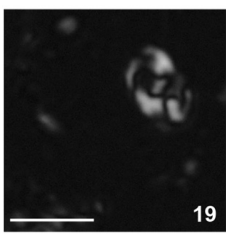

W-5, 755

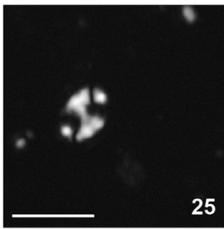

O. terrazetus W-4, 307.84

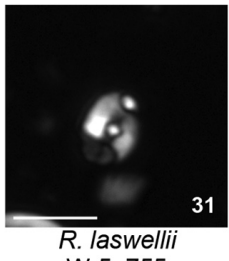

W- 5,755

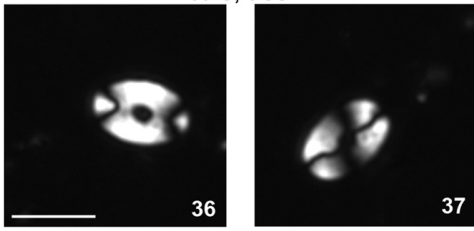

R. bukryi W-5, 755

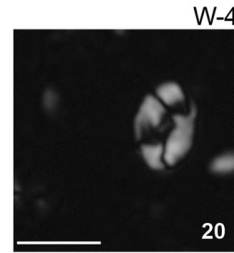

20

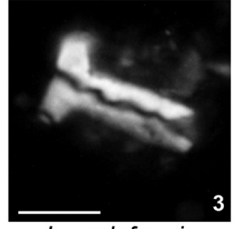

L. maleformis W-7, $1000 \mathrm{~m}$

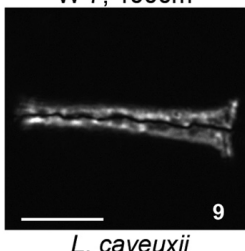

L. cayeuxii W-4 274.32
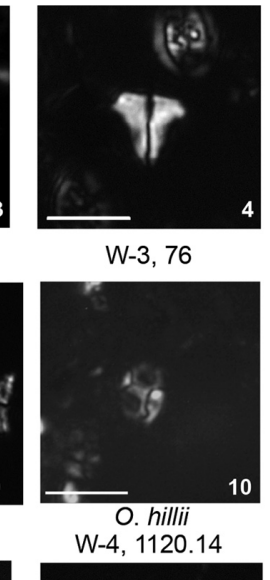

W-3, 76
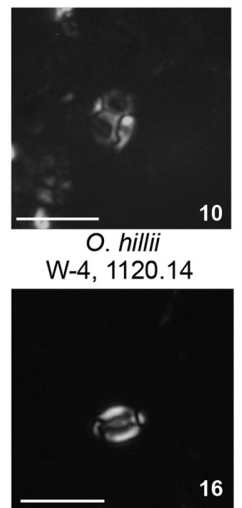

cf. Bil. wadeae W-6, 969

Bil. wadeae

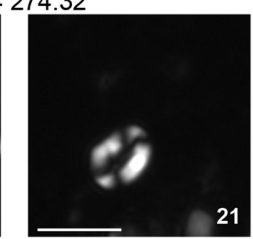

M. lesliae W-5, 755
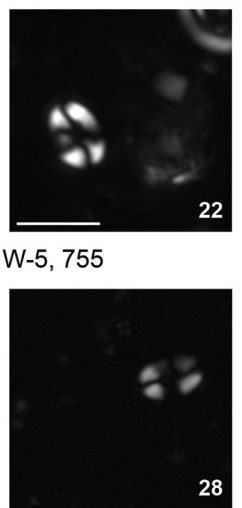

O. terrazetus W-4, 307.84

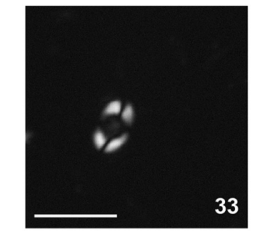

cf. $R$. laswellii W-4, 646.18

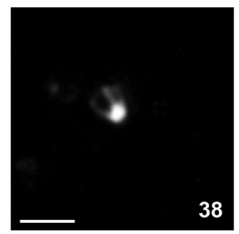

D. leariae $\mathrm{W}-7,730$
22

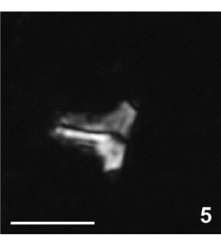

W-3, 76
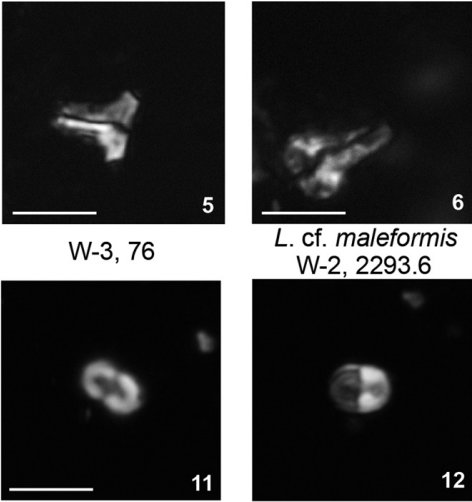

W-2, 2293.6

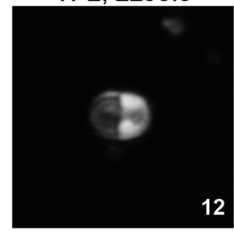

Bif. mchanae W-4, 1295.4
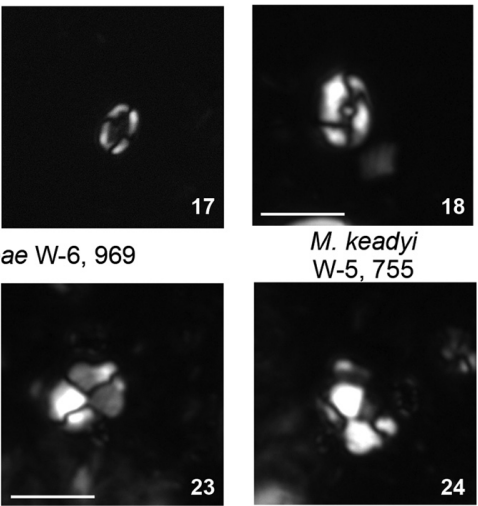

Oct. multiplus W-5, 755

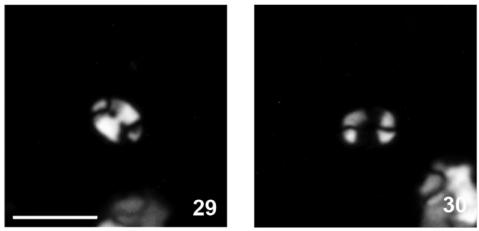

O. cf. terrazetus W-7, 730
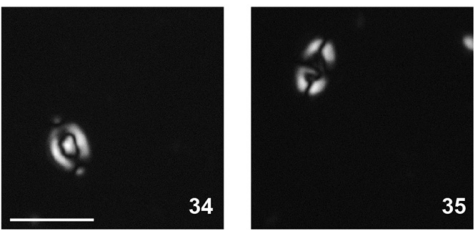

cf. R. laswellii W-4, 646.18

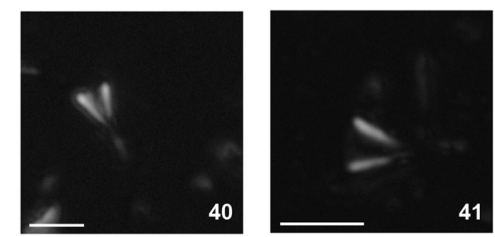

N. baileyi

W-4, 835.15

W-5, 755

Plate 9. Holococcoliths common genera: Calculites, Lucianorhabdus, Owenia. Rarer genera: Bifidalithus, Bilapillus, Munarinus, Octolithus, Ottavianus, Russellia, Duocameratus, Nicholasia. 


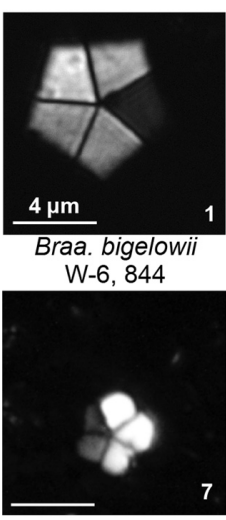

W-7, 790

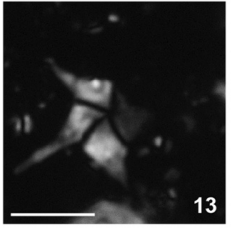

W-3, 3

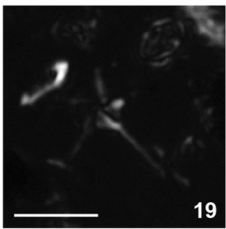

W-3, 76

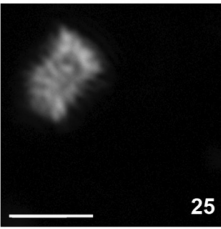

W-3, 685.8

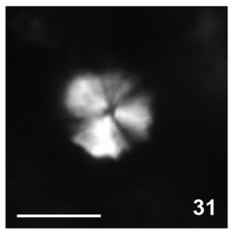

W-2, 2293.6

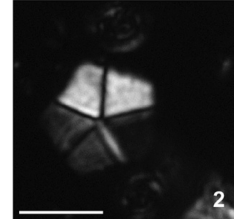

W-3, 686

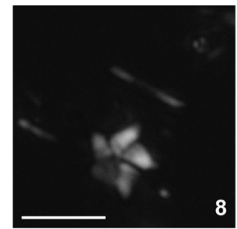

Braa. turbinea W-3, 3

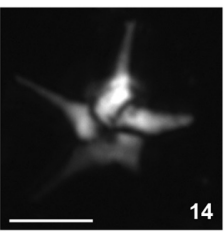

W-4, 168

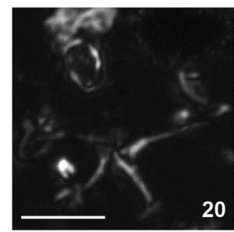

20

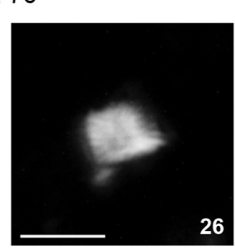

W-7, 910

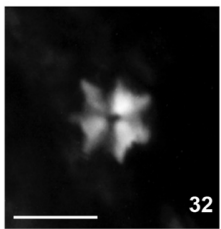

W-7, 910

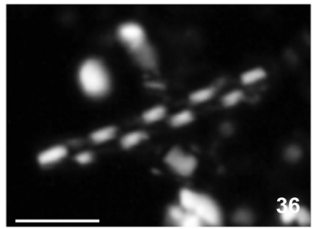

M. decoratus

W-7, 620

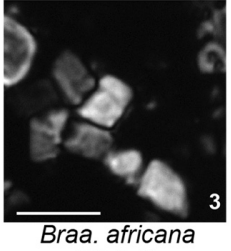

W-3, 3

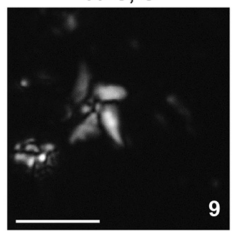

W-3, 3

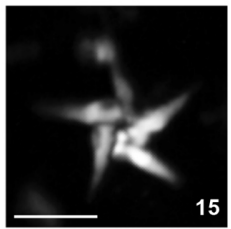

W-7, 620

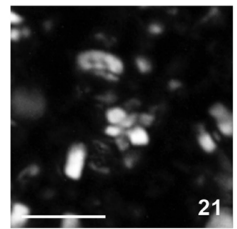

H. gardetiae W-8, 681

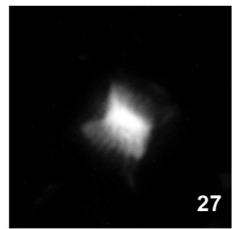

27

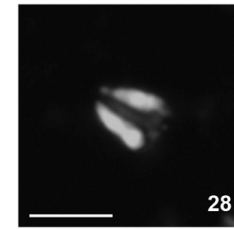

28
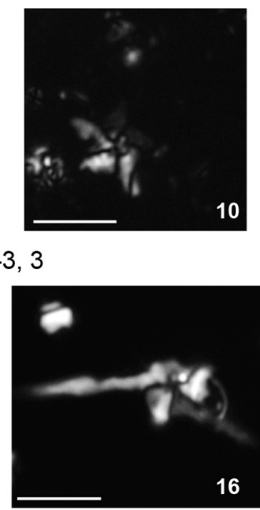

W-4, 228

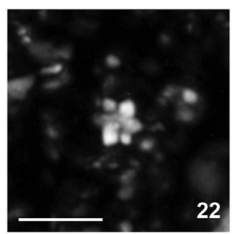

\section{2}

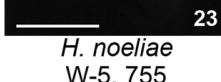

W-5, 755

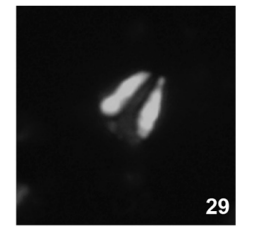

W-4, 1254.3

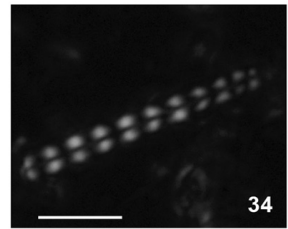

M. undosus $\mathrm{W}-3,228.6$

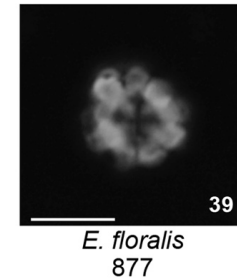

23

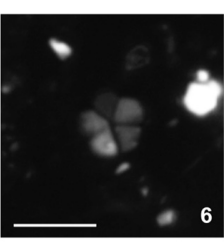

W- $4,344.4$

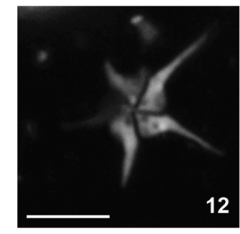

W-4, 168

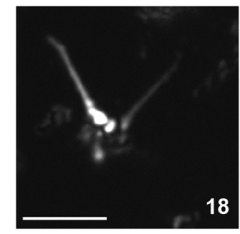

W-3, 76

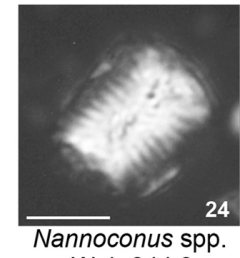

W-4, 944.9

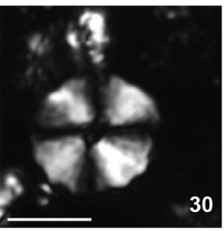

W-3, 686

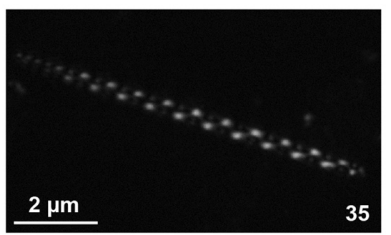

W-4, 216.1

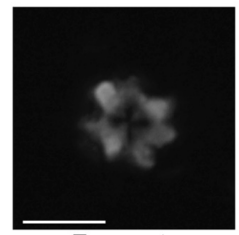

E. moratus

877

Plate 10. Nannoliths Braarudosphaerales Braarudosphaeraceae: Braarudosphaera, Bukryaster, Hexalithus; Nannoconaceae: Nannoconus. Nannoliths inc sedis Microrhabdulaceae: Lithraphidites, Microrhabdulus Polycyclolithaceae: Eprolithus. 


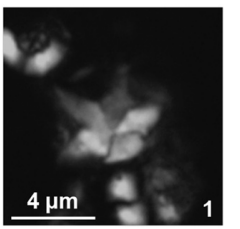

$\mathrm{W}-4,1280.4$

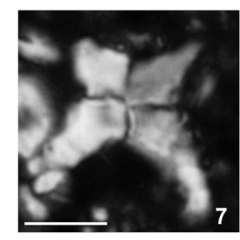

W-8, 681

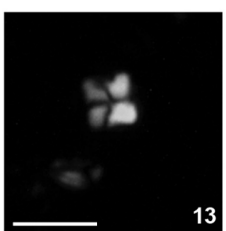

Q. gartneri

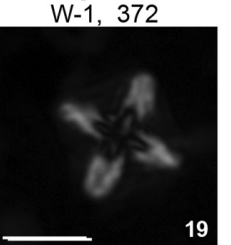

Mic. staurophora W-5, 755

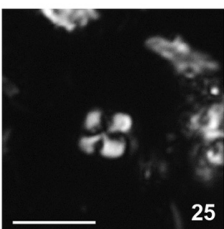

cf. Mic. adumbrata

W-3, 686

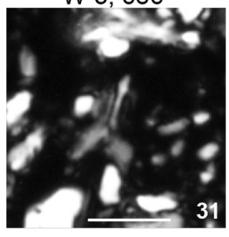

W-8, 672

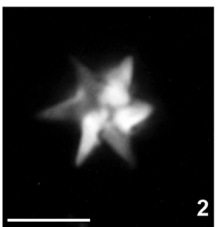

W-7, 790

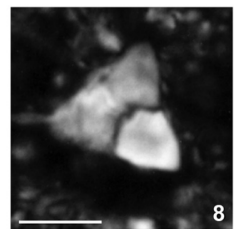

Unip. trifidus

W-8, 681

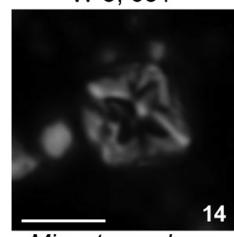

Mic. staurophora W-5, 560

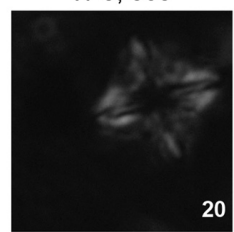

20

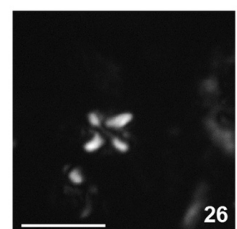

Mic. cf. prinsii W-3, 305

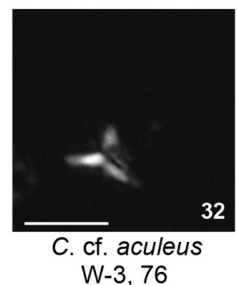

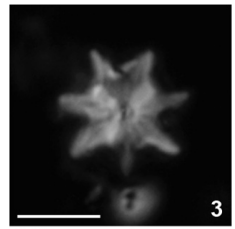

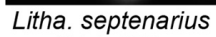

W-4 689

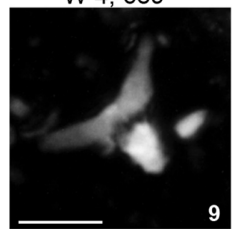

W-8, 681

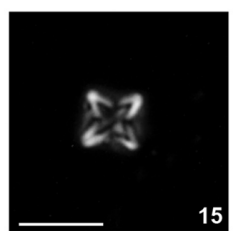

W-7, 850

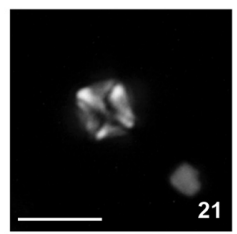

Mic. cf. staurophora W-8, 843

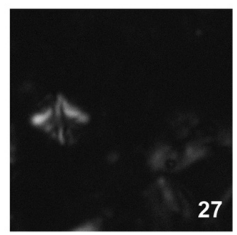

27

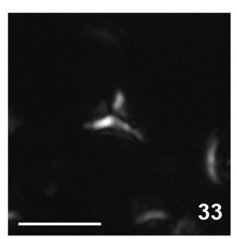

W-3, 76

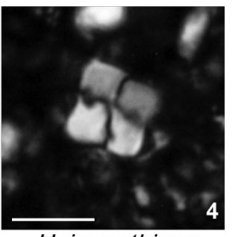

Unip. gothicus

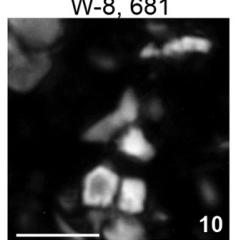

W-8, 681
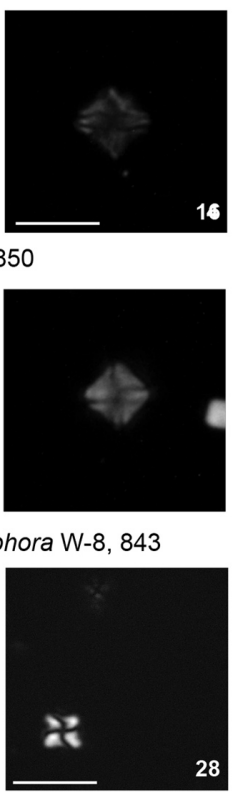

W-3, 305

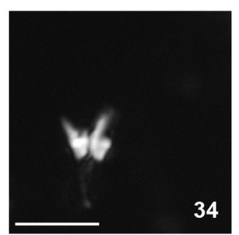

W-3, 686

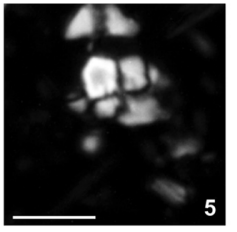

W-8, 681

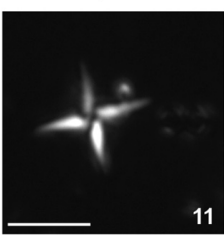

Undifferentiated (could be confused with U. sissinghii) $\mathrm{W}-5,755$

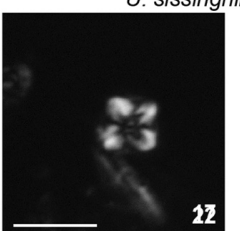

W-3, 624

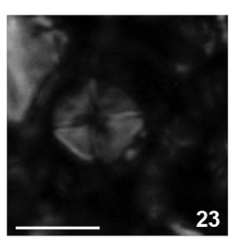

W-8, 681

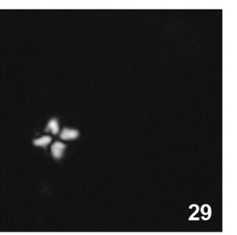

29

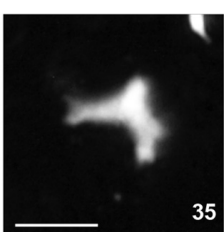

cf. M. furcatus W-7, 790

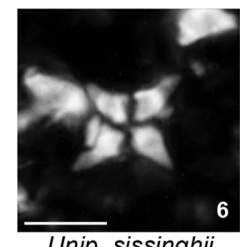

Unip. sissinghii

W-8, 681
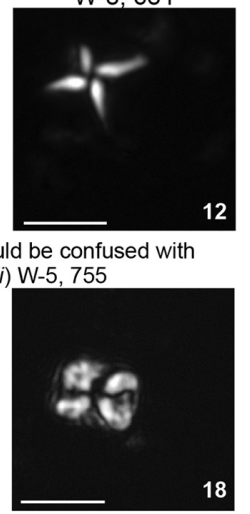

W-3, 685.8
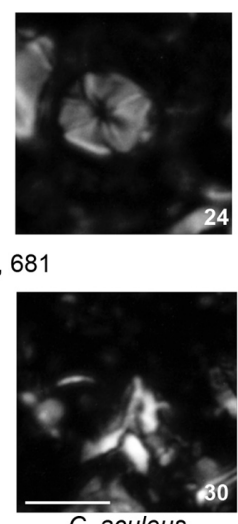

C. aculeus W-8, 681

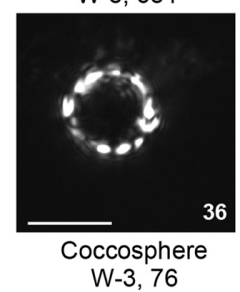

Plate 11. Nannoliths inc sedis Polycyclolithaceae: Lithastrinus, Uniplanarius, Quadrum, Micula. Nannoliths inc sedis - other: Ceratolithoides, Marthasterites. 


\section{Derivation of name}

The name derivation is after the Al Arma Mountains (pronounced as "Al Ormah"), where the type section of the Aruma Group-Formation was first described; "Ormah" is also the true Arabic pronunciation of Aruma.

\section{Diagnosis}

This is a small species $(3.5-4.5 \mu \mathrm{m})$ of Staurolithites with bright bicyclic rim. The central area is filled by a thick, birefringent cross that is slightly offset from the axial position. The cross and the bicyclic rim show very high birefringence under the cross-polarised light microscope.

\section{Differentiation}

This new species is distinguished from other Staurolithites species by its small size, high birefringence and complex construction of the cross-bars that fills most of the central area.

\section{Holotype}

Plate 4, fig. 9 (fig. 10 same specimen).

Holotype dimensions

$L=4.5 \mu \mathrm{m}, W=3.9 \mu \mathrm{m}$.

Paratype

Plate 4, fig. 11 (fig. 12 same specimen).

Type locality

W-6, NW Oman.

Type level

UC12-13 ${ }^{\mathrm{TP}}$, late Santonian to early Campanian.

\section{Occurrence}

W-4, W-6, W-7, late Santonian to late Campanian

Chiastozygus fahudensis sp. nov.

Plate 4, figs. 39-41.

\section{Derivation of name}

The name derivation is after the Fahud oil field (W-4), from which the species was first identified.

\section{Diagnosis}

This is a medium-sized $(5-7 \mu \mathrm{m})$ species of Chiastozygus with a simple unicyclic, indistinct rim and characteristic bright cross with a rosette-shaped central feature.

\section{Differentiation}

This new species is distinguished from other Chiastozygus species by its distinctive bright cross and the rosette-shaped central feature.

Holotype

Plate 4, fig. 39 (fig. 40 same specimen).

Holotype dimensions

$L=6 \mu \mathrm{m}, W=4.6 \mu \mathrm{m}$.

Paratype

Plate 4, fig. 41.

Type locality

W-3, N Oman.

Type level

$\mathrm{UC} 14^{\mathrm{TP}}$, early Campanian.

\section{Occurrence}

W-3, W-4, W-6, W-7, W-8; late Coniacian to late Campanian.

Data availability. Full data for the study are currently inaccessible as they are protected by a Petroleum Development Oman (PDO) and Ministry of Oil and Gas of Oman (MOG) confidentiality agreement with the authors. The published study data are released by PDO and MOG approval to be published in the Journal of Micropalaeontology. Contact the first author for more information about the data and the cited industry reports.

Supplement. The supplement related to this article is available online at: https://doi.org/10.5194/jm-38-25-2019-supplement.

Author contributions. Data collection, sample analyses and interpretation have been undertaken by ZAR under the supervision of TDJ. ZAR wrote the paper with guidance from TDJ.

Competing interests. The authors declare that they have no conflict of interest. 
Acknowledgements. Thank you to PDO for sponsoring the study and providing the data and to MOG for their permission to publish this study. Thanks to Peter Osterloff (Shell UK) and Stephen Packer (Millennia SC Ltd) for their comments on the paper. Jackie Lees is thanked for her comments on the Late Cretaceous species identification.

Edited by: Emanuela Mattioli

Reviewed by: Nicolas Thibault, Silvia Gardin, and

Christian Linnert

\section{References}

Al-Wosabi, A. and Alaug, S.: Calcareous nannofossil biostratigraphy of the Late Campanian-Early Maastrichtian Age, Block 16, Jiza'-Qamar Basin, Eastern Yemen, Arab. J. Geosci., 6, 35813594, https://doi.org/10.1007/s12517-012-0642-2, 2013.

Barrier, E. and Vrielynck, B.: Paleotectonic Maps of the Middle East, Middle East Basins Evolution Programme, CGMW, Atlas, Maps, 1-14, 2008.

Bechennec, F., Le Metour, J., Rabu, D., Bourdillon-de-Grissac, C., de Wever, P., Beurrier, M., and Villey, M.: The Hawasina Nappes: stratigraphy, palaeogeography and structural evolution of a fragment of the south-Tethyan passive continental margin, in: The Geology and Tectonics of the Oman Region, edited by: Robertson, A. H. F., Searle, M. P., and Ries, A. C., Geological Society Publishing House, London, 213-223, 1990.

Boote, D. R. D., Mou, D., and Waite, R. I.: Structural evolution of the Suneinah Foreland, Central Oman Mountains, in: The geology and tectonics of the Oman Region, edited by: Robertson, A. H., Searle, M. P., and Ries, A. C., Geological Society Publishing House, London, 397-418, 1990.

Bown, P. R. and Young, J. R.: Mesozoic calcareous nannoplankton classification, Journal of Nannoplankton Research, 19, $21-$ 36, 1997.

Bown, P. R. and Young, J. R.: Techniques, in: Calcareous Nannofossil Biostratigraphy, edited by: Bown, P. R., Kluwer Academic Publishers, London, 16-28, 1998.

Bown, P. R., Lees, J. A., and Young, J. R.: Calcareous nannoplankton evolution and diversity through time, in: Coccolithophores from Molecular Processes to Global Impact, edited by: Thierstein, H. R. and Young, J. R., Springer-Verlag, Berlin, 481-508, 2004.

Bukry, D.: Coccolith and silicoflagellate stratigraphy, Tasman Sea and southwestern Pacific Ocean, Deep Sea Drilling Project Leg 21, Initial Rep. Deep Sea, 21, 885-893, https://doi.org/10.2973/dsdp.proc.21.127.1973, 1973.

Burnett, J.: New species and new combinations of Cretaceous nannofossil and a note on the origin of Petrarhabdus (Deflandre) Wind and Wise, Journal of Nannoplankton Research, 19, 133146, 1997.

Burnett, J.: Upper Creraceous, in: Calcareous Nannofossil Biostratigraphy, edited by: Bown, P. R., Kluwer Academic Publishers, London, 132-199, 1998.

Cramer, B. S., Miller, K. G., Barrett, P. J., and Wright J. D.: Late Cretaceous-Neogene trends in deep ocean temperature and continental ice volume: Reconciling records of benthic foraminiferal geochemistry $\left(\delta^{18} \mathrm{O}\right.$ and $\left.\mathrm{Mg} / \mathrm{Ca}\right)$ with sea level history, J. Geo- phys. Res., 116, C12023, https://doi.org/10.1029/2011jc007255, 2011.

Crux, J. A.: Albian calcareous nannofossils from the Gault Clay of Munday's Hill (Bedfordshire, England), J. Micropalaeontol., 10, 203-221, https://doi.org/10.1144/jm.10.2.203, 1991.

Eleson, J. W. and Bralower, T. J.: Evidence of changes in surface water temperature and productivity at the Cenomanian/ Turonian Boundary, Micropaleontology, 51, 319-332, https://doi.org/10.2113/gsmicropal.51.4.319, 2005.

Erba, E.: Middle Cretaceous calcareous nannofossil from the western Pacific (Leg 129): evidence for paleoequatorial crossings, Proceedings of the Ocean Drilling Program Scientific Results, 129, 189-201, https://doi.org/10.2973/odp.proc.sr.129.119.1992, 1992.

Erba, E.: Calcareous nannofossil and Mesozoic oceanic anoxic events, Mar. Micropaleontol., 52, 85-106, https://doi.org/10.1016/j.marmicro.2004.04.007, 2004.

Erba, E., Castradori, D., Guasti, G., and Ripepe, M.: Calcareous nannofossil and Milankovitch cycles: the example of the Albian Gault Clay Formation (southern England), Palaeogeogr. Palaeoecl., 93, 47-69, https://doi.org/10.1016/00310182(92)90183-6, 1992.

Faris, M. and Abu Shama, A. M.: Calcareous nannofossils of the Campanian-Maastrichtian Sudr Formation in Abu Zenima area, West Central Sinai, Egypt, J. Paleontol., 6, 251-274, 2006.

Farouk, F., Thibault, N., Jaff, R., Faris, M., Ahmad, F., and Khashaba, A.: An integrated study of upper Campanian-lower Maastrichtian carbon isotopes and calcareous plankton biostratigraphy of the Kurdistan Region, northeastern Iraq, Cretaceous Res., 82, 64-80, https://doi.org/10.1016/j.cretres.2017.09.020, 2018.

Farouk, S. and Faris, M.: Late Cretaceous calcareous nannofossil and planktonic foraminiferal bioevents of the shallow-marine carbonate platform in the Mitla Pass, west central Sinai, Egypt, Cretaceous Res., 33, 50-65, https://doi.org/10.1016/j.cretres.2011.08.002, 2012.

Fisher, C. G. and Hay, W. W.: Calcareous nannofossil as indicators of Mid-Cretaceous paleofertility along an ocean front, U. S. Western Interior, in: Special Paper 332: Evolution of the Cretaceous Ocean-Climate System, edited by: Barrera, E. and Johnson, C. C., The Geological Society of America, USA, 161-180, 1999.

Forbes, G. A., Jansen H. S. M., and Schreurs, J. (Eds.): Lexicon of Oman subsurface stratigraphy: Reference guide to the stratigraphy of Oman's hydrocarbon basins, Gulf PetroLink, Bahrain, 2010.

Foroughi, F., Gadin, S., Lotfali Kani, A., and Vahidinia, M.: Calcareous Nannofossil biostratigraphy of Campanian strata (Abtalkh Formation) from East of KoppehDagh Basin, NE Iran, Cretaceous Res., 70, 55-70, https://doi.org/10.1016/j.cretres.2016.10.002, 2017.

Friedrich, O., Norris, R. D., and Erbacher, J.: Evolution of middle to Late Cretaceous oceans - a 55 my record of Earth's temperature and carbon cycle, Geology, 40, 107-110, https://doi.org/10.1130/g32701.1, 2012.

Glennie, K. W., Boeuf, M. G., Hughes-Clarke, M. H. W., MoodyStuart, M., Pilaar, W. F., and Reinhardt, B.: Geology of the Oman Mountains, Royal Dutch Geological and Mining Society, Amsterdam, 1974. 
Grun, W. and Zweili, F.: Das kalkige Nannoplankton der DoggerMalm-Grenz im Berner Jura bei Liesberg (Schweiz), Jb. Geol. Bundesanst., 123, 231-341, 1980.

Hardas, P. and Mutterlose, J.: Calcareous nannofossil assemblages of Oceanic Anoxic Event 2 in the equatorial Atlantic: Evidence of an eutrophication event, Mar. Micropaleontol., 66, 52-69, https://doi.org/10.1016/j.marmicro.2007.07.007, 2007.

Herrle, J. O.: Paleoceanographic and paleoclimatic implications on mid-Cretaceous black shale formation in the Vocontian Basin and the Atlantic: evidence from calcareous nannofossil and stable isotopes, Tubinger Mikropalaontologische Mitteilungen, 27, 1-115, 2002.

Herrle, J. O., Pross, J., Friedrich, O., and Hemleben, C.: Short-term environmental changes in the Cretaceous Tethyan Ocean: micropaleontological evidence from the Early Albian Oceanic Anoxic Event lb, Terra Nova, 15, 14-19, https://doi.org/10.1046/j.1365-3121.2003.00448.x, 2003.

Hughes Clarke, M. W.: Stratigraphy and rock unit nomenclature in the oil producing area of interior Oman, J. Petroleum Geol., 11, 5-60, https://doi.org/10.1306/bf9ab689-0eb6-11d78643000102c1865d, 1988.

Keller, G.: Cretaceous climate, volcanism, impacts, and biotic effects, Cretaceous Res., 29, 754-771, https://doi.org/10.1016/j.cretres.2008.05.030, 2008.

Kita, Z., Watkins, D., and Bergen, J.: A new calcareous nannofossil species of the genus Helicolithus from the Santonian and its biostratigraphic significance in the Cretaceous Western Interior Seaway, Journal of Nannoplankton Research, 36, 77-82, 2016.

Lauer, G.: Manual of Upper Cretaceous calcareous nannoplankton (Arkhangelskiellaceae) based on the Fiqa Formation of Central Oman (Santonian-Campanian), internal SIPM report, 1973.

Lees, J., Bown, P., and Mattioli, E.: Problems with proxies? Cautionary tales of calcareous nannofossil paleoenvironmental indicators, Micropaleontology, 51, 333-343, https://doi.org/10.2113/gsmicropal.51.4.333, 2005.

Lees, J., Bown, P., and Young, J.: Photic zone palaeoenvironments of the Kimmeridge Clay Formation (Upper Jurassic, UK) suggested by calcareous nannoplankton palaeoecology, Palaeogeogr. Palaeocl., 235, 110-134, https://doi.org/10.1016/j.palaeo.2005.09.026, 2006.

Lees, J. A.: Calcareous nannofossil biogeography illustrates palaeoclimate change in the Late Cretaceous Indian Ocean, Cretaceous Res., 23, 537-634, https://doi.org/10.1006/cres.2003.1021, 2002.

Lees, J. A.: New and rarely reported calcareous nannofossil from the Late Cretaceous of coastal Tanzania: outcrop samples and Tanzania Drilling Project Sites 5, 9 and 15, Journal of Nannoplankton Research, 29, 39-65, 2007.

Lees, J. A. and Bown, P. R.: Upper Cretaceous calcareous nannofossil biostratigraphy, ODP Leg 198 (Shatsky Rise, northwest Pacific Ocean), in: Proceedings of the Ocean Drilling Program, Scientific Results Volume 198, edited by: Bralower, T. J., Premoli Silva, I., and Malone, M. J., 1-60, 2005.

Linnert, C. and Mutterlose, J.: Biometry of the Late Cretaceous Arkhangelskiella group: ecophenotypes controlled by nutrient flux, Cretaceous Res., 30, 1193-1204, https://doi.org/10.1016/j.cretres.2009.06.001, 2009a.

Linnert, C. and Mutterlose, J.: Evidence of increasing surface water oligotrophy during the Campanian-Maastrichtian boundary interval: Calcareous nannofossils from DSDP Hole 390A (Blake Nose), Mar. Micropaleontol., 73, 26-36, https://doi.org/10.1016/j.marmicro.2009.06.006, 2009 b.

Linnert, C., Mutterlose, J., and Herrle, J. O.: Late Cretaceous (Cenomanian-Maastrichtian) calcareous nannofossils from Goban Spur (DSDP Sites 549, 551): Implications for the palaeoceanography of the proto North Atlantic, Palaeogeogr. Palaeocl., 299, 507-528, https://doi.org/10.1016/j.palaeo.2010.12.001, 2011.

Linnert, C., Mutterlose, J., and Bown, P. R.: Biometry of Upper Cretaceous (Cenomanian-Maastrichtian) coccoliths - a record of long-term stability and interspecies size shifts, Revue de Micropaleontologie, 57, 125-140, https://doi.org/10.1016/j.revmic.2014.09.001, 2014a.

Linnert, C., Robinson, S. A., Lees, J. A., Bown, P. R., Pérez Rodríguez, I., Petrizzo, M. R., Falzoni, F., Littler, K., Arz, J. A., and Russell, E. E.: Evidence for global cooling in the Late Cretaceous, Nat. Commun., 5, 4194, https://doi.org/10.1038/ncomms5194, 2014b.

Linnert, C., Engelke, J., Wilmsen, M., and Mutterlose, J.: The impact of the Maastrichtian cooling on the marine nutrient regime-Evidence from mid-latitudinal calcareous nannofossils, Paleoceanography, 31, 694-714, https://doi.org/10.1002/2015pa002916, 2016.

Lippard, S. J., Shelton, A. W., and Gass, I. G.: The ophiolite of Northern Oman, Blackwell Scientific Publications, London, 1986.

Mandur, M.: Late Cretaceous Calcareous Nannofossil Biostratigraphy and Paleoecology in the Northwestern Desert, Egypt, Arab. J. Sci. Eng., 41, 2271-2284, https://doi.org/10.1007/s13369-0151872-x, 2016.

Miller, K. G., Kominz, M. A., Browning, J. V., Wright, J. D., Mountain, G. S., Katz, M. E., Sugarman, P. J., Cramer, B. S., Christie-Blick, N., and Pekar, S. F.: The Phanerozoic record of global sea-level change, Science, 310, 1293-1298, https://doi.org/10.1126/science.1116412, 2005.

Müller, C., Higazi, F., Hamdan, W., and Mroueh, M.: Revised stratigraphy of the Upper Cretaceous and Cenozoic series of Lebanon based on nannofossil, in: Evolution of the Levant Margin and Western Arabia Platform since the Mesozoic, edited by: Homberg, C. and Bachmann, M., The Geological Society of London, London, 287-303, 2010.

Mutterlose, J., Bornemann, A., and Herrle, J.: Mesozoic calcareous nannofossils - state of the art, Palaeont. Z., 79, 113-133, https://doi.org/10.1007/bf03021757, 2005.

Osterloff, P., Al Harthy, A., Nasser Al Rahmah, M., and Al Zadjali, F.: Basal Fiqa Formation, North Oman: a stratigraphic review, internal PDO report, 2001

Packer, S. R.: Fiqa Formation study IV: Biostratigraphic analysis of selected intervals from PDO wells Qalah-2, Burhaan-5, Hanya-1, Wadi Umayri-1, Wadi Umayri-2 and Jahiz-1, North Oman, internal Millennia report for PDO, 2002.

Perch-Nielsen, K.: Mesozoic calcareous nannofossil, in: Plankton Stratigraphy, edited by: Bolli, H. M., Saunders, J. B., and PerchNielsen, K., Cambridge University Press, Cambridge, 329-426, 1985.

Prins, B. and Roersma, H. J.: Late Santonian to Late Campanian calcareous nannoplankton from the Fiqa Formation, Central Oman, internal SIPM report, 1983. 
Razmjooei, M., Thibault, N., Kani, A., Mahanipour, A., Boussah, M., and Korte, C.: Coniacian-Maastrichtian calcareous nannofossil biostratigraphy and carbon-isotope stratigraphy in the Zagros Basin (Iran): consequences for the correlation of Late Cretaceous Stage Boundaries between the Tethyan and Boreal realms, Newsl. Stratigr., 47, 183-209, https://doi.org/10.1127/00780421/2014/0045, 2014.

Razmjooei, M., Thibault, N., Kani, A., Dinarès-Turell, J., Pucéat, E., Shahriari, S., Radmacher, W., Jamali, A., Ullmann, C., Voigt, S., and Cocquerez, T.: Integrated bio- and carbon-isotope stratigraphy of the Upper Cretaceous Gurpi Formation (Iran): A new reference for the eastern Tethys and its implications for largescale correlation of stage boundaries, Cretaceous Res., 91, 312340, https://doi.org/10.1016/j.cretres.2018.07.002, 2018.

Robertson, A.: Upper Cretaceous Muti formation: transition of a Mesozoic carbonate platform to a foreland basin in the Oman Mountains, Sedimentology, 34, 1123-1142, https://doi.org/10.1111/j.1365-3091.1987.tb00596.x, 1987.

Roth, P. H.: Mid-Cretaceous calcareous nannoplankton from the central Pacific: Implications for paleoceanography, Initial Rep. Deep Sea., 62, 471-489, https://doi.org/10.2973/dsdp.proc.62.113.1981, 1981.

Roth, P. H.: Preservation of calcareous nannofossil and fine-grained carbonate particles in mid-Cretaceous sediments from the southern Angola Basin, Site 530, Initial Rep. Deep Sea., 75, 651-655, https://doi.org/10.2973/dsdp.proc.75.112.1984, 1984.

Roth, P. H. and Bowdler, J. L.: Middle Cretaceous calcareous nannoplankton biogeography and oceanography of the Atlantic Ocean, The Deep Sea Drilling Project: A Decade of Progress, Soc. Sediment. Geol. SP, 32, 517-546, https://doi.org/10.2110/pec.81.32.0517, 1981.

Shafik, S.: Late Cretaceous nannofossil biostratigraphy and biogeography of the Australian western margin, BMR bulletin, 295, 1-164, 1990.

Shamrock, J. L. and Watkins, D. K.: Evolution of the Cretaceous calcareous nannofossil genus Eiffellithus and its biostratigraphic significance, Cretaceous Res., 30, 1083-1102, https://doi.org/10.1016/j.cretres.2009.03.009, 2009.

Sikkema, W.: Micropalaeontological zonation and range charts of the Cretaceous in Oman, internal PDO report, 1991.

Sissingh, W.: A preliminary calcareous nannoplankton zonation of the Cretaceous-Early Paleocene interval, internal SIPM report, 1974.

Sissingh, W.: Biostratigraphy of Cretaceous calcareous nannoplankton, Geol. Mijnbouw, 56, 37-65, 1977.

Street, C. and Bown, P. R.: Palaeobiogeography of Early Cretaceous (Berriasian-Barremian) calcareous nannoplankton, Mar. Micropaleontol., 39, 265-291, https://doi.org/10.1016/s03778398(00)00024-4, 2000.

Styzen, M.: Cascading counts of nannofossil abundance, Journal of Nannoplankton Research, 19, p. 49, 1997.

Takahashi, G.: Sample preparation for X-ray fluorescence analysis III. Pressed and loose powder methods, Rigaku Journal, 31, 2630, 2015.

Thibault, N.: Biometric analysis of the Arkhangelskiella group in the upper Campanian-Maastrichtian of the Stevns-1 borehole, Denmark: taxonomic implications and evolutionary trends, Geobios, 43, 639-652, https://doi.org/10.1016/j.geobios.2010.06.002, 2010.
Thierstein, H. R.: Mesozoic calcareous nannoplankton biostratigraphy of marine sediments, Mar. Micropaleontol., 1, 325-362, https://doi.org/10.1016/0377-8398(76)90015-3, 1976.

Thierstein, H. R.: Selective dissolution of Late Cretaceous and earliest Tertiary calcareous nannofossil: experimental evidence, Cretaceous Res., 2, 2-12, https://doi.org/10.1016/01956671(80)90023-3, 1980.

Thierstein, H. R.: Late Cretaceous nannoplankton and the change at the Cretaceous-Tertiary boundary, in: The Deep Sea Drilling Project: a decade of progress, edited by: Warme, J. E., Douglas, R. G., and Winterer, E. L., Society of Economic Paleontologists and Mineralogists, Tulsa, 355-394, 1981.

van Hinsbergen, D. J. J., de Groot, L. V., van Schaik, S. J., Spakman, W., Bijl, P. K., Sluijs, A., Langereis, C. G., and Brinkhuis, H.: A paleolatitude calculator for paleoclimate studies (model version 2.1), PLoS ONE, 10, 1-21, https://doi.org/10.1371/journal.pone.0126946, 2015.

Varol, O.: Quantitative analysis of the Arkhangelskiella cymbiformis Group and Biostratigraphic usefulness in the North Sea Area, J. Micropalaeontol., 8, 131-134, https://doi.org/10.1144/jm.8.2.131, 1989.

Varol, O.: Nannofossil biostratigraphy of Petroleum Development Oman wells Al Husain-1, Musallim-2 and Yibal-5, internal Varol Research report for PDO, 1996.

Varol, O.: Nannofossil biostratigraphy of Petroleum Development Oman wells Mabrouk-2 \& Al Ghubar-15, internal Varol Research report for PDO, 1997.

Wagreich, M.: A review of low-latitude Tethyan calcareous nannoplankton assemblages of the Cretaceous, in: New Aspects on Tethyan Cretaceous Fossil Assemblages, edited by: Kollmann, H. A. and Zapfe, H., Springer-Verlag, Vienna, 45-55, https://doi.org/10.1007/978-3-7091-5644-5_4, 1992.

Watkins, D. K., Wise, S. W., Pospichal, J. J., and Crux, J.: Upper Cretaceous calcareous nannofossil biostratigraphy and paleoceanography of the Southern Ocean, in: Microfossil and Oceanic Environments, the proceedings of the ODP and Marine Biosphere international conference, Aberystwyth, Wales, 19-21 April 1994, 355-381, 1996.

Williams, J. R. and Bralower, J.: Nannofossil assemblages, fine fraction stable isotopes, and the paleoceanography of the Valanginian-Barremian (Early Cretaceous) North Sea Basin, Paleoceanography, 10, 815-839, https://doi.org/10.1029/95pa00977, 1995.

Wind, F. H.: Maestrichtian-Campanian nannofloral prov inces of the southern Atlantic and Indian Oceans, in: Deep drilling results in the Atlantic Ocean: continental margins and paleoenvironment, edited by: Talwani, M., Hay, W. W., and Ryan, W. B. F., American Geophysical Union, Washington DC, 123-137, 1979.

Wise, S. W.: Mesozoic and Cenozoic calcareous nannofossil recovered by Deep Sea Drilling Project Leg 71 in the Falkland Plateau Region, Southwest Atlantic Ocean, Initial Rep. Deep Sea., 71, 481-550, https://doi.org/10.2973/dsdp.proc.71.121.1983, 1983.

Wise, S. W.: Mesozoic-Cenozoic history of calcareous nannofossil in the region of the Southern Ocean, Palaeogeogr. Palaeocl., 67, 157-179, https://doi.org/10.1016/0031-0182(88)90127-7, 1988.

Wyton, J. and Bown, P.: Palaeoecological trends in TuronianConiacian (Late Cretaceous) calcareous nannofossils from Chalk Group sections, SE England, Journal of Nannoplankton Research, 29, 31-37, 2007. 
Young, J. R., Bergen, J. A., Bown, P. R., Burnett, J. A., Fiorentino, A., Jordan, R. W., Kleijne, A., van Niel, B. E., Ton Romein, A. J., and von Salis, K.: Guidelines for coccolith and calcareous nannofossil terminology, Paleontology, 40, 875-912, 1997.
Ziegler, M. A.: Late Permian to Holocene Paleofacies Evolution of the Arabian Plate and its Hydrocarbon Occurrences, GeoArabia, 6, 445-504, 2001. 